\title{
International Comparisons of Real Product, 1820-1990: An Alternative Data Set ${ }^{1}$
}

\author{
Leandro Prados de la Escosura \\ Universidad Carlos III de Madrid \\ E-mail: prados@clio.uc3m.es
}

\begin{abstract}
In this paper a new set of current price estimates of per capita income, adjusted for each currency's purchasing power, is presented for a sample of mainly OECD countries during more than one and a half centuries. A short-cut method is used to derive current price comparisons for countries and periods in which aggregate PPPs are not available. Current price estimates of PPP-adjusted GDP appear to be more economically sound than constant price figures as economic agents react to current, not to constant, prices, and, therefore, would allow more appropriate cross-country comparisons of productivity and welfare. Country rankings in the new data set are different from those provided by earlier cross-country comparisons; among the new finding earlier U.S. leadership and the closer relative position of Britain and France over the 19th century can be highlighted.
\end{abstract}

Widespread renewed efforts to produce historical national accounts have rendered many widely used data sets obsolete. Drawing on this research, economic historians have constructed new historical comparisons of product per head across countries by extrapolating present-day levels of GDP per person adjusted for differences in purchasing power backward with volume indices of product per

1 An earlier version of this paper was written while I was a visiting fellow at All Souls College, Oxford, and at the London School of Economics and I thank my hosts Charles Feinstein and Nick Crafts for their advice and encouragement. I gratefully acknowledge comments by participants in seminars at Leuven, Montecatini, the London School of Economics, the Washington area economic history workshop, Warwick, the $12^{\text {th }}$ IEHA Congress, Lund, Carlos III, and IVIE. I am particularly indebted to Bart van Ark, Steve Broadberry, Paul David, Stan Engerman, James Foreman-Peck, Knick Harley, Alan Heston, Mark Harrison, Tim Hatton, Agustín Llona, Angus Maddison, Kevin O’Rourke, Joan Rosés, Peter Solar, Joachim Voth, John Wallis, Eugene White, Jeff Williamson, and especially Patrick O'Brien and Isabel Sanz, for their very useful criticism. Roberto Cortés-Conde, Charles Feinstein, Rainer Fremdling, Rita Hjerppe, Edwin Horlings, Ölle Krantz, Kevin O’Rourke, Sevket Pamuk, Jaime Reis, Albrecht Ritschl, Max Schulze, Thomas David, Jean-Claude Toutain, and Jan Luiten van Zanden gave me advice about national sources and kindly provided me with unpublished data for Argentina, Austria, Belgium, Finland, France, Germany, Ireland, the Netherlands, Portugal, Sweden, Switzerland, Turkey, and the U.K. Research funding was provided by the Spanish Ministry of Education Grant PB95-0294 and Fundación Argentaria. The usual disclaimer applies. 
head. ${ }^{2}$ My aim is to produce revised estimates of PPP-adjusted levels of output at current prices as an alternative to the familiar constant price comparisons, thereby improving cross-sectional comparability. ${ }^{3}$ These estimates yield new evidence for the ongoing debate on catching up and convergence. ${ }^{4}$ Although subject to a margin of error, they are probably closer to "real" (PPP-adjusted) product per head than "nominal" (i.e., exchange rate converted) income. For many purposes, they are superior to the widely accepted figure for GDP per capita expressed in 1960, 1970, or 1990 dollars (Bairoch (1976, 1978); Maddison (1982, 1991, 1995)). My paper opens with a discussion of the short-cut methods to obtain PPP-adjusted per capita income. Section two applies the short-cut method to data in panel form for the years 1950-1990. Finally, section three includes a new historical data set for PPP-corrected real product at current prices and compares it with previous evidence.

\section{COMPARISONS ACROSS SPACE AND TIME: A SHORT-CUT METHOD}

The substitution of purchasing power parity (PPP) rates of conversion for the accessible trading exchange rates has become common practice in comparisons of GDP across countries as the view that trading exchange rates do not measure relative price levels and do not move with them overtime has become widespread. ${ }^{5}$ The International Comparisons Project (ICP) and, more recently, the International Comparisons of Output and Productivity (ICOP) group have provided purchasing-power-parity-adjusted exchange rates to convert GDP ex-

2 The best estimates are those by Maddison (1982, 1991, 1995), who in his latest work made a rigorous examination of the best GDP measures for 56 countries, with various adjustments for coverage of the national accounts and territorial change. He specifie whether the original series were expenditure-based, industry of origin, or income. Then he merged the time series, the overwhelming majority volume indices, with the benchmark estimates of GDP level adjusted by a Geary-Khamis multilateral converter from the International Comparisons Project (ICP) sources for most of the 56 sample countries and from the Penn World Table 5.5 for 143 nonsample countries.

3 PPP is define as the number of units of a country's currency required to purchase the same amount of goods and services in the country as one dollar would buy in the US (Ahmad (1994:54). The PPP concept has two versions. One is a conversion factor to transfer data from one currency into another, and this paper deals with it. Another refers to the PPP theory of exchange rates, which in its strong version asserts that the equilibrium exchange rate equals the ratio of domestic to foreign price levels, while in its weak form it relates only to changes in both variables. Cf. Officer (1976) and Rogoff (1996).

${ }^{4}$ A detailed analysis of the new results and its implications for this debate is presented in Prados de la Escosura (2000a).

${ }^{5}$ For widely accepted and sound theoretical reasons conversions at nominal rates of exchange are not acceptable for purposes of comparing levels of output and welfare across countries (Balassa (1961, 1964), Samuelson (1964), Kravis and Lipsey (1983), Bhagwati (1984)). Empirical evidence gathered in recent years strongly rejects the conventional results obtained through the trading exchange rate converter (Summers and Heston (1991), van Ark (1993)), as trading exchange rates reflec only the purchasing power of goods traded internationally and are influence by capital movements, exchange controls and speculation (Maddison (1995:162)). 
pressed in national currency into internationally comparable units of account (van Ark (1993)). ${ }^{6}$ Both ICP and ICOP have concentrated their research on recent years and only a few PPPs have been constructed for earlier periods, and mostly from the output side, with the exception of Williamson (1995), who used an income approach. ${ }^{7}$ The reason for the dearth of PPP estimates for years before 1960 is the high costs in terms of time and resources involved in the construction of PPP converters (Ahmad (1998)). In addition, data for the pre-World War II era are scarce and unreliable.

Yet plausible estimates of GDP levels expressed in a common standard, unaffected by yearly disturbances in exchange rates, and covering a large number of countries are a precondition for comparative economic history. Backcasting present-day PPP adjusted GDP levels on the basis of volume indices of real product or growth rates derived from national accounts data represents the most convenient alternative available to those who aim to conduct comparisons across space and time. ${ }^{8}$ Thus, in his latest contribution, which includes a sample of countries with series covering nearly two centuries, Angus Maddison (1995) expresses the comparisons in 1990 Geary-Khamis "international" dollars. ${ }^{9}$

Unfortunately, by accepting a distant PPP as the point of reference, the

${ }^{6}$ Data requirements to produce PPPs from an industry of origin approach are more demanding than date requirements to do so from the expenditure side. Prices for output and inputs are needed for the former while only prices for the fina product are necessary for the latter. Heston and Summers (1996:22) criticize the production side comparisons approach because of the assumptions made about the relations of gross output to value added and unit values to prices of specifie items. In addition, comparable input-output tables will be required to compare GDP from net value added by output sector across countries (Heston et al. (1994)). Finally, low coverage of the so-called "unit value ratios" is another problem in ICOP estimates. Cf. Jorgenson (1993) for a detailed criticism.

${ }^{7}$ In addition to O'Brien and Keyder (1978) and Fremdling (1991), PPP computations have been made for commodity output, cf. for agriculture, van Zanden (1991) and O'Brien and Prados de la Escosura (1992), and for manufacturing, Broadberry and Fremdling (1990), Broadberry (1994, 1997), Burger (1997), and Dormois and Bardini (1995).

${ }^{8}$ Besides, the fixed-bas real (PPP-adjusted) product data have the presentation advantage that growth rates corresponding to common currency units are the same as those calculated in national accounts. A significan strand of the literature defends the view that the best estimates of growth rates are those obtained from national accounts (Bhagwati and Hansen (1973); Isenman (1980); Kravis and Lipsey (1991); Maddison (1991, 1995)), on the grounds that "using domestic prices to measure growth rates is more reliable, because those prices characterize the trade offs faced by the decision making agents" (Nuxoll (1994)). Kravis and Lipsey (1991:458) argued that growth rates derived from domestic prices were preferable because of the basket of goods used "reflecte the preferences of purchasers of fina product in one of the years being compared." The drawback for international comparisons derives from the fact that equal growth in two different countries for a given good contributes differently to aggregate growth.

9 Geary-Khamis "international" prices are not actual market prices but a weighted average of the prices observed in each country, where countries' shares in world output are used as weights. Such a set of prices is inevitably arbitrary and is biased toward the larger and richer countries. Alternative weighting, such as using world population shares instead of output shares, has been suggested (Isenman (1980)) but not put into practice. Other multilateral methods, such as EKS, are used by OECD and EUROSTAT in an attempt to solve the problem. The EKS alternative represents a multilateralization of the the Fisher "ideal" binary index (Ahmad (1998); Dowrick (1998)). 
procedure, as pioneered by Bairoch (1976) and Maddison (1982), introduces distortions and ambiguities in intertemporal comparisons. For example, estimates expressed in 1990 PPP-adjusted dollars allow comparison between the benchmark year (1990) and any other year within the observed time series (conducted in terms of a basket of goods weighted and priced according to the tastes and preferences of 1990), but the fixe end-year estimate does not in theory allow for a comparison between any other pair of years in the time span. Moreover, the validity and interest of the comparisons depends on how stable the basket of goods and services used to construct the original PPP converters remains over time. ${ }^{10}$ Historically, as growth occurs the composition of production, consumption and relative prices all vary, and the economic meaning of comparing real product per head based upon remote PPPs becomes entirely questionable so it could happen that comparisons based upon PPP projections might generate larger errors than comparisons using conventional exchange rates [ER, thereafter] (Eichengreen (1986)). ${ }^{11}$ Furthermore, the selection of a particular PPP benchmark converter produces worrying dispersion in relative income levels (Maddison (1991, 1995); O'Rourke and Williamson (1997)). Table 1 illustrates this point by comparing at different dates $(1950,1975,1990)$ levels of real product per head relative to the U.S. for a sample of countries obtained through the extrapolation of PPP-adjusted levels of per capita GDP taken from alternative ICP benchmarks with a common set of national volume indices of product per head. Absolute deviations of extrapolated levels of product per head with respect to those ICP directly estimated for each date's benchmark appear to be above 5\% and often much higher, while showing a high dispersion. This findin constitutes a clear warning against the risks of mismeasuring countries' relative levels of income over time derived from the use of a single ICP benchmark, say PPP-adjusted 1990 dollars.

Short-cut solutions to the construction of PPP converters could, then, be a plausible solution to spatial comparisons of income levels and might mitigate the formidable index number problem involved in conducting over time comparisons based upon data for a single benchmark year. Short-cut methods involve regression analysis whereby the national, or comparative, price level (i.e., PPP/ER ratios) is regressed upon nominal (i.e., exchange-rate converted) product per head and a set of additional explanatory variables for a sample of countries for which PPP data are available. ${ }^{12}$ Later, the established formal relationship is used to infer

10 Thus, relative prices would usually change after a while, rendering the base year weights obsolete.

11 Summers and Heston $(1988,1991)$ have attempted to mitigate the Laspeyres fixed-inde problem through the reconciliation of national accounts and international benchmark data by producing a chain index real GDP series in which the growth rate for any period is based upon international prices closer to this period. The results of Summers and Heston (1991) have been disputed because of their lack of transparence and ambiguity and later reconsidered by their own authors in PWT5.5 (Summers and Heston (1993)). Maddison (1991, 1995), for example, argued that the "consistentizing" of the successive ICP rounds is a more probable source of error than national accounts.

12 Alternatively, real (i.e., PPP-adjusted) income per capita is taken as the dependent variable. 
TABLE 1

Relative Levels of Real Product per Head under Alternative ICP Benchmarks ${ }^{a}$ [United States $=1$ ] (Real Product per Head Extrapolated over Time with a Common Set of Volume Indices Taken from National Accounts)

\begin{tabular}{|c|c|c|c|c|c|c|c|c|}
\hline \multirow[b]{2}{*}{ Year } & \multirow{2}{*}{$\begin{array}{c}1950 \\
\text { Bench- } \\
\text { mark }\end{array}$} & \multirow{2}{*}{$\begin{array}{c}1970 \\
\text { Bench- } \\
\text { mark }\end{array}$} & \multirow{2}{*}{$\begin{array}{l}1975 \\
\text { Bench- } \\
\text { mark }\end{array}$} & \multirow{2}{*}{$\begin{array}{l}1980 \\
\text { Bench- } \\
\text { mark }\end{array}$} & \multirow{2}{*}{$\begin{array}{c}1985 \\
\text { Bench- } \\
\text { mark }\end{array}$} & \multirow{2}{*}{$\begin{array}{c}1990 \\
\text { Bench- } \\
\text { mark }\end{array}$} & \multicolumn{2}{|c|}{$\begin{array}{c}\text { Absolute deviation } \\
\text { (log of extrapolated to } \\
\text { directly computed levels) }\end{array}$} \\
\hline & & & & & & & Average & Std deviation \\
\hline \multicolumn{9}{|l|}{1950} \\
\hline Belgium & 0.552 & 0.585 & 0.547 & 0.605 & 0.527 & 0.612 & 0.062 & 0.034 \\
\hline Denmark & 0.610 & & 0.724 & 0.742 & 0.654 & 0.759 & 0.163 & 0.057 \\
\hline France & 0.571 & 0.531 & 0.570 & 0.552 & 0.504 & 0.572 & 0.048 & 0.047 \\
\hline Germany & 0.441 & 0.395 & 0.434 & 0.420 & 0.378 & 0.439 & 0.066 & 0.058 \\
\hline Italy & 0.352 & 0.344 & 0.359 & 0.401 & 0.365 & 0.396 & 0.066 & 0.048 \\
\hline Netherlands & 0.512 & 0.607 & 0.613 & 0.648 & 0.602 & 0.660 & 0.201 & 0.037 \\
\hline Norway & 0.639 & & & 0.686 & 0.567 & 0.544 & 0.091 & 0.057 \\
\hline U.K. & 0.616 & 0.629 & 0.680 & 0.739 & 0.679 & 0.723 & 0.112 & 0.056 \\
\hline \multicolumn{9}{|l|}{1975} \\
\hline Austria & & & 0.741 & 0.726 & 0.671 & 0.756 & 0.047 & 0.038 \\
\hline Belgium & 0.808 & 0.856 & 0.801 & 0.886 & 0.772 & 0.897 & 0.065 & 0.039 \\
\hline Denmark & 0.714 & & 0.846 & 0.867 & 0.765 & 0.888 & 0.086 & 0.056 \\
\hline France & 0.885 & 0.823 & 0.883 & 0.855 & 0.780 & 0.886 & 0.047 & 0.046 \\
\hline Germany & 0.869 & 0.779 & 0.856 & 0.828 & 0.744 & 0.865 & 0.059 & 0.051 \\
\hline Ireland & & & 0.469 & 0.522 & 0.426 & 0.437 & 0.091 & 0.015 \\
\hline Italy & 0.647 & 0.633 & 0.660 & 0.737 & 0.671 & 0.728 & 0.057 & 0.039 \\
\hline Japan & & 0.657 & 0.736 & 0.747 & 0.704 & 0.725 & 0.047 & 0.040 \\
\hline Netherlands & 0.680 & 0.806 & 0.814 & 0.861 & 0.799 & 0.877 & 0.068 & 0.061 \\
\hline Spain & & & 0.593 & 0.596 & 0.544 & 0.560 & 0.049 & 0.033 \\
\hline UK & 0.664 & 0.678 & 0.733 & 0.796 & 0.732 & 0.780 & 0.064 & 0.034 \\
\hline \multicolumn{9}{|l|}{1990} \\
\hline Belgium & 0.760 & 0.805 & 0.753 & 0.833 & 0.725 & 0.843 & 0.085 & 0.049 \\
\hline Denmark & 0.718 & & 0.851 & 0.873 & 0.769 & 0.893 & 0.110 & 0.079 \\
\hline France & 0.888 & 0.825 & 0.886 & 0.858 & 0.783 & 0.890 & 0.049 & 0.048 \\
\hline Germany & 0.915 & 0.820 & 0.902 & 0.872 & 0.783 & 0.911 & 0.063 & 0.057 \\
\hline Ireland & & & 0.539 & 0.600 & 0.489 & 0.502 & 0.091 & 0.063 \\
\hline Italy & 0.718 & 0.702 & 0.733 & 0.817 & 0.745 & 0.808 & 0.090 & 0.044 \\
\hline Japan & & 0.815 & 0.914 & 0.928 & 0.874 & 0.900 & 0.043 & 0.032 \\
\hline Netherlands & 0.634 & 0.753 & 0.760 & 0.804 & 0.746 & 0.819 & 0.105 & 0.080 \\
\hline Norway & 0.951 & & & 1.021 & 0.843 & 0.809 & 0.145 & 0.079 \\
\hline Spain & & & 0.611 & 0.615 & 0.561 & 0.578 & 0.049 & 0.015 \\
\hline UK & 0.676 & 0.690 & 0.745 & 0.810 & 0.745 & 0.793 & 0.089 & 0.052 \\
\hline
\end{tabular}

${ }^{a}$ Figures in bold correspond to directly computed estimates.

out of sample (countries and years) levels of real per capita product using the estimated PPP/ER ratios. The underlying hypothesis behind the short-cut approach is that a structural relationship exists between the price level and basic economic characteristics (Kravis and Lipsey (1987)). ${ }^{13}$

${ }^{13}$ Estimating short-cuts is clearly a different task from estimating a model since the short-cut 
Short-cut solutions to the problem of comparing GDP across countries were originally provided by David (1972), Clague and Tanzi (1972) and Kravis et al. (1978b). Nevertheless the rationale behind the technique must be defended and elaborated further. Short-cut estimates can be based exclusively on the ERconverted income as the explanatory variable (David (1972, 1973); Balassa (1964, 1973); Hulsman-Vejsová (1975)). Alternatively, the estimates could include additional variables to nominal income and, thereby, break the monotonic relationship between PPP-converted and ER-adjusted income by which two countries with identical nominal income per capita will have the same real income (Clague and Tanzi (1972); Kravis et al. (1978b); Isenman (1980); Summers et al. (1980); Summers and Heston (1984); Clague (1986a, 1986b); Ahmad (1996)).

Convergent and divergent forces affect price relationships across countries. International trade leads, through competition, to the integration of markets which tends to equalize (commodity and factor) prices over time. Conversely, the isolation of national economies derived from geography, history, and policies prevents market integration and so impedes price convergence (Kravis et al. (1978b)). Kravis and his associates posited a stable relationship between purchasing-power-parity- and trading-exchange-rate-converted income conditional upon their degree of openness, relative to a "star" or reference country, in order to capture structural change. ${ }^{14}$ It was expected that the more exposed an economy was to international competition, the narrower the differential between the PPP-converted and the ER-adjusted income would be while, conversely, the differential would widen for countries protected by location, high transport costs, and impediments to trade imposed by governments. ${ }^{15}$

method's goal is to fin a reliable empirical relationship between PPP-adjusted income and a set of variables, including ER-converted income, for which data are available for out-of-sample countries or years, while in a model causal relationships are explored. Notwithstanding this caveat, a rationale should exist in the election of variables for the short-cut estimation (Clague (1986b)). An alternative to short-cut estimates could be provided by the so-called "reduced information method," which requires price data for only a selected group of goods and services. However, data availability makes this procedure more space- and time-restrictive than straightforward short-cut estimation. For examples of historical applications of the "reduced information method," cf. footnote 6 . For the best present-day example, cf. Ahmad (1988).

14 They relied on ICP (Phase II) finding for 16 countries in 1970 (Kravis et al. (1978a)).

15 Kravis and his associates used the ratio of exports and imports of goods and services to GDP as an indicator for openness and included another variable, price isolation, which looked at the concordance of changes in a country's prices (ER-adjusted) with changes in world prices, as measured by the mean squared difference between the country's and the world's GDP implicit deflators Price isolation would widen the PPP-ER differential; the rationale is that the wider the inflatio differential, the deeper the country's isolation and, hence, the lower the prices for nontradables. However, the opposite effect could also be predicted for price isolation: The higher a country's inflation the higher its prices relative to the world prices and, consequently, the lower its PPP-adjusted income. In subsequent work, Summers and Heston (1984), using ICP Phase III data for 34 countries in 1975 from Kravis et al. (1982), together with data for ICP Phase II, dismissed the price isolation variable to concentrate on the relationship between the PPP-adjusted per capita income, on the one hand, and the ER-converted per capita income and the relative openness measure, on the other. This method was, by 
in the more exposed economy, a larger proportion of the commodities that enter fina production are traded, and commodity prices are thus pulled closer to world levels. This raises factor prices in the commodity producing (traded goods) sector. As a result of the tendency towards factor price equalization within the economy, it also increases factor prices in the non-traded goods sector (service and construction industries), and thus raises the fina prices of such products.

Against this view, Clague $(1985,1986 a)$ argued that import restrictions are associated with higher price levels and, thus, the more open an economy, that is, the lower its import barriers, the lower its price level should be. ${ }^{16}$ Kravis and Lipsey $(1987,100)$ qualifie KHS earlier views by admitting, along HeckscherOhlin lines, that "trade not only operates directly in pulling prices of tradables toward greater uniformity but affects the price of non-tradables by tending to raise the price of relatively abundant factors" and the direction of the price levelopenness relationship varies with factor proportions. Thus, in poor countries, where labor is the abundant factor, and nontradables are labor-intensive, the expected relationship would be positive, that is, ceteris paribus, more openness should be linked to higher prices, whereas, in rich, capital-intensive countries, the more open the economy the lower its price level. ${ }^{17}$

The ambiguity in the expected sign of the relationship between the price level and the degree of openness led other authors to explore alternative explanations of the PPP-ER differential, such as relative skills and natural resource endowments and the inflo of foreign capital. ${ }^{18}$

the way, abandoned by Summers and Heston $(1988,1991)$, who chose, as an alternative, the so-called post-adjustment price data from the United Nations, that is, the reduced information provided by UN estimates on the cost of living for international civil servants in capital cities around the world. Despite its limited representativeness of the cost of living for a country's average citizen, such an indicator has a very high correlation with PPP-adjusted income (Kravis et al. (1978b:226)). It is interesting to notice, however, that Kravis and his associates did not use post-adjustment data because, "particularly for a Western basket of goods, the ratio of capital city prices to prices in the rest of the country tends to be much higher in many African countries than is the case elsewhere" (p. 228).

${ }^{16}$ KHS, who presumably had in mind LDCs, were aware that "a lack of openness due to protective commercial policies could lead to higher prices for traded goods" but, in their view, the effect of protection on the aggregate price level is not clear as protection would also have a depressing impact on nontradables' prices, since tariffs or quantitative restrictions on imports shelter import-substituting industries (that is, tradables). They argued that "to the extent development policies push up the internal prices of traded goods relative to world prices, they lead to an exaggeration of nominal GDP relative to real GDP but to the extent that they depress the prices of non-traded goods they have the opposite effect"' (KHS:222).

${ }^{17}$ Clague (1988:241) pointed out that the choice of underlying theoretical model matters. In the specifi factors model the tariff shifts labor toward the import-substituting sector, raising wages and consequently the price of services and the aggregate price level. In turn, in the capital-labor model the effect of the tariff on factor prices depends upon relative factor endowments in the tradable sector. If import-competing sectors are capital-intensive, the tariff reduces wages and raises the price of capital, causing the price of services to fall.

18 Isenman (1980), on the basis of the same sample of 16 countries for 1970 (ICP Phase II) used by 
Given the theoretical foundations for the short-cut approach to deriving PPP rates of exchange, the challenge for economic historians is to explore the way in which such methods might be applied to derive real income levels for times past. Eichengreen (1986) proposed that historians should adopt the method KHS used to obtain PPP-adjusted real income for nonbenchmark countries in their crosssectional data set to derive comparable levels of GDP per head. Such an approach has the advantage of generating cross-country comparisons of real product at current prices. Thus, it would provide a more acceptable economic depiction of a country's relative position in the world than conjectural numbers based upon PPP converters for remote years. After all, people live in terms of and react to current, not to constant prices. Nevertheless the method rests upon a debatable assumption about the extent to which a structural relationship found between the price levels and a series of explanatory variables (including the nominal income) for the late $20^{\text {th }}$ century can be projected backward to derive plausible conjectures of relative levels of GDP for earlier periods of history. ${ }^{19}$ Arbitrary as they are, the assumptions involved in short-cut estimation methods seem more acceptable than the assumption of no structural change over time implicit in the familiar backward projection of PPP-adjusted levels of present-day estimates of GDP to the past.

\section{REGRESSION ANALYSIS}

In this section Eichengreen's suggestion will be taken up. The variables selected and used derive from contributions to the debate on short-cut estimates of real income. My estimation procedure aimed at establishing a structural relationship, for each country, between its price level (hereafter PL, define as the $\mathrm{PPP} / \mathrm{ER}$ ratio), on the one hand, and nominal GDP per head (expressed in US dollars using the trading rate of exchange), plus an additional set of explanatory variables, on the other. ${ }^{20}$ Parameters from the resulting equation will then be used

KHS, produced alternative short-cut estimates of real income per head in which the degree of openness
and price isolation was replaced by the relative endowment of skills. Later, Clague (1986a, 1986b)
investigated, for a sample of 31 countries in 1975 (ICP Phase III), the extent to which differences in
country rankings derived from choosing the PPP or the exchange rate as a converter of national GDP
into a common currency (US\$) could be attributed to the endowment of natural resources (share of
minerals in GDP), the international position of a country (as measured by the trade balance and tourist
receipts), productivity differentials in services (proximated by educational attainment level), and
macroeconomic policies (measured by the growth of money supply). A further exploration for a
60-country sample was carried out by Clague (1988) for 1980 (ICP Phase IV). The latest attempt to
provide short-cut alternatives to the KHS method has been carried out by Ahmad (1996) for different
data sets from ICP Phases III, IV, and V (covering 34, 60, and 56 countries in 1975, 1980, and 1985,
respectively), firs separately and then pooled. However, it was an alternative data set for 76 countries
with 1985 as the base year from which the short-cut regressions were derived.
19 The proposal, which was never put into practice, would be the extrapolation of a structural
relationship observed for a sample of countries to an off-sample epoch and group of countries. Balassa
(1973) gave a cautious negative answer to the similar, but not identical, proposal by David (1972) of
applying a structural relationship found for DCs to LDCs.

${ }_{20}$ Alternatively, the level of real product per head (PPP-adjusted), expressed relative to the United 
together with the values from each independent variable to derive PLs for nonbenchmark countries (i.e., out of sample years and countries). A new set of real income estimates in current prices will be obtained by deflatin levels of nominal GDP per head by the PL. ${ }^{21}$

Some elaboration on the type of PPP chosen as the numerator of the dependent variable $(\mathrm{PL}=\mathrm{PPP} / \mathrm{ER})$ seems necessary. Binary versus multilateral approaches to cross-country comparisons come into the discussion when short-cut methods are used to produce historical estimates of real GDP. Transitivity and characteristicity conflic in PPP comparisons, and they represent a trade-off between binary and multilateral approaches to PPP (Dabán et al. (1997)). ${ }^{22}$ Thus, the lower the number of countries and the more homogeneous their expenditure patterns, the stronger will be the appeal of a binary approach. Characteristicity in this case will prevail despite the fact that comparisons among countries can only logically be carried out through each country's binary comparison to the reference country (usually the United States), and the results are not transitive.

In practice, the binary approach dominates most ICOP papers and pre-WorldWar-II studies, including Maddison's own $(1982,1989,1991)$ long-run comparisons. Furthermore, despite failing to satisfy transitivity, additivity, and country invariance conditions, PPPs obtained through the binary approach provide a clearer economic meaning than multilateral methods. ${ }^{23}$ In the present case, a sample of countries from Europe and European offshoots overseas (plus Japan) that corresponds roughly to the present-time OECD is considered. As Maddison (1982) pointed out, these are nations that tended to converge toward the patterns of demand and productivity of the star country (the United States). Moreover, data availability favors the choice of a binary approach because PPPs for 1950 were derived through the binary method (Gilbert and Kravis (1954); Gilbert and associates (1958)). The adoption of the more theoretically correct multilateral approach would confin all the useable information to the post-1970 period.

The ICP convention is to defin Laspeyres and Paasche binary indices by regarding the higher income country in any pair of countries, as the base situation. That is, when the basket of goods used to compare two countries corresponds to the star country, a Laspeyres purchasing power parity exchange rate will be

States, could be selected as the dependent variable. It has been argued that when real product is the dependent variable nominal (ER-converted) product as an independent variable explains most of the variance alone and leaves little room to allow for additional explanatory variables (Clague (1986b); Isenman (1980)). Isenman (1980) used the inverse of the PL, the so-called ER deviation. Alternatively, KHS and Ahmad (1996) chose to investigate the determinants of PPP-adjusted per capita income.

${ }^{21}$ This is identical to dividing the level of GDP per head, expressed in each country's own currency [Y], by the estimated PPP. That is, $(\mathrm{Y} / \mathrm{ER}) / \mathrm{PL}=(\mathrm{Y} / \mathrm{ER}) /(\mathrm{PPP} / \mathrm{ER})=\mathrm{Y} / \mathrm{PPP}$.

${ }^{22}$ Characteristicity is the extent to which the sample of items price-compared and the weights used in the aggregation reflec those of the countries being compared (Kravis (1984:10).

${ }^{23}$ Cf. Maddison (1982). The two best-known multilateral methods, Geary-Khamis and EKS present problems of economic interpretation. For the former, so called "international prices" are obtained through arbitrary weighting, that is, countries' shares in world output while the latter is a generalised the Fisher "ideal" index, whose significanc is uncertain (cf. Dowrick (1998)). 
computed (as a ratio of the aggregated value of the U.S. basket expressed in each country's own prices to that for one valued in U.S. prices). If, instead, the basket for the nonstar country is considered, then a Paasche PPP will be obtained. In turn, this means that when any country's GDP, expressed in national currency, is converted into a common currency (U.S. \$) through a Paasche PPP, a Laspeyres value index will result. ${ }^{24}$

In fact, only when Paasche PPPs are chosen and, therefore, Laspeyres value measures are obtained (that is, when GDP is estimated at U.S. relative prices for the whole set of countries), will transitivity be kept within the star-country system (Kravis (1984:8-10). ${ }^{25}$ David (1973:1269) favored the use of a uniform set of prices when time series and cross-section data are pooled, and noted that

the uniformity of the direction of the expected bias present in Laspeyres quantity comparison between all possible pairs of countries ... can be guaranteed by selecting the uniform price weights from the country which is situated at the upper extreme of the range of real per capita incomes. ${ }^{26}$

Moreover, binary PPP-converted GDP estimates do not suffer the incomparability problem of the multilateral approach that emerges when country coverage changes over time, since a set of countries is compared simultaneously (i.e., multilaterally) and, therefore, the addition or deletion of countries alters the relationship between any pair of countries (Ahmad (1994:57-60)).

Finally, the Laspeyres PPP-converted real product (that is, real GDP obtained through a Paasche PPP) is the binary comparison that comes closest to the multilateral Geary-Khamis PPP-converted per capita GDP since, in the latter, countries are weighted according to size. However, both Paasche and GearyKhamis PPPs tend to be vulnerable to the substitution bias or Gerschenkron effect, that is, the tendency for the quantity index to be lower the higher the correlation between its own price structure and the price structure used for valuation. The reason for this is that valuation by a country's own prices leads to a lower aggregate valuation of its GDP because the set of quantities produced has adapted to this set of prices. As Kravis (1984:9) observed, countries tend to consume relatively more of those goods for which prices are relatively low. ${ }^{27} \mathrm{In}$ other words, when Paasche PPPs are used the relative position of the star country

${ }^{24}$ In algebraic form, $\Sigma P_{i} Q_{i} /\left(\Sigma P_{i} Q_{i} / \Sigma P_{0} Q_{i}\right)=\Sigma P_{0} Q_{i}$, where $P(Q)$ are prices (quantities) for each country $(i)$ or the star country, the United States $(0)$. In other words, current GDP at national currency divided by a Paasche PPP equals a "quantity" Laspeyres index. Conversely, a Paasche "quantity" index will result when a Laspeyres PPP is used.

25 Transitivity through the star country, as in Paasche binary comparisons, represents, however, the disadvantage of making the results depend upon the selection of the base country.

26 Against this view, Balassa $(1973,1974)$ suggested the Fisher "ideal" index as the suitable weighting scheme that was supported from a theoretical position by Samuelson (1974).

${ }^{27}$ In fact, the actual PPP-adjusted relative level of a country will be overestimated by a Lapeyres quantity index and understimated by a Paasche quantitity index (cf. Dowrick (1998)). Balassa (1973:1260) states that "assumming identical and homothetical indifference maps in the countries under comparison, Hicks' substitution theorem will lead to the conclusion that a country's consumption pattern will be 'slanted' towards goods whose prices are relatively low in that country." 
tends to worsen as compared with its position in alternative results derived through Laspeyres or Fisher PPPs.

My selection of independent variables presupposed explanatory potential and data availability for some 20 countries covering a time span of more than one and a half centuries. Along with nominal per capita income, the independent variables considered here include openness, measured by the trade ratio to GDP corrected for the country's size, and the net inflo of capital proxied by the current account balance, as a proportion to GDP, since data are widely available after 1913 and, for most advanced countries, for decades before World War I.

A word should be said firs about the exclusion of an education variable in the short-cut equation. ${ }^{28}$ There is agreement among scholars about the association between education and higher income levels. Clague (1986b:315), for example, stated that "the level of education may serve along with nominal income to give an indication of the level of real income," while Isenman (1980:67) pointed that "the KHS PPP [income] estimates may be a relatively useful index of welfare, or of meeting 'basic needs' in poor countries." Actually, a similar concept underlies the UNDP's Human Development Index which combines longevity, access to knowledge (measured by education indicators), and real income in order to provide a minimal measure of welfare. ${ }^{29}$ Moreover, the data set presented in this paper provides new evidence against testing the new growth theory in which the initial level of human capital, often approximated by education enrollment, is an explanatory variable for a country's growth rate. Since the new real per capita income data set could be used to test growth theory and to construct Human Development indices over the long-run, I do not include education indicators as regressors in the short-cut estimate of the PL that will be, in turn, used to derive measures of real product per head. No variable was included for natural resource endowment since this factor is highly correlated with size (Perkins and Syrquin (1989)) and will most probably be captured by the size variable. ${ }^{30}$

The definitio of each variable and summary statistics are provided in Table 2. Brief comments on each independent variable including its expected correlation with the price level will be necessary before the results from the econometric exercise are presented.

First, nominal GDP per head is assumed to capture the price level in the tradable sector of the economy. Figure 1 shows, for the countries and dates for

${ }^{28}$ Isenman (1980) put forward the hypothesis that when services are skill-intensive, higher schooling leads to a lower price for services and, consequently, to a lower price level.

${ }^{29}$ Isenman (1980), p. 67, actually observed a close correlation between secondary enrollment and literacy "which is a determinant, along with per capita income, of infant mortality and life expectancy," that is, the components of the HDI. For a historical construction of Human Development indices, cf. Steckel and Floud (1997) and Crafts (1997).

${ }^{30}$ However, the expected relation of natural resource endowment with the PL would have been positive (Clague and Tanzi (1972)), whereas the one predicated for PL and size here is negative. Other potential variables, such as the share of labor employed in agriculture and the contribution of agriculture to GDP were not taken into the short-cut regression because they should be captured in the natural endowments variable. Moreover, while they are associated to lower levels of development in Europe, this is not necessarily the case in the New World. 
TABLE 2

Variable Definition and Descriptive Statistics (All Variables Are Expressed Relative to U.S.)

\begin{tabular}{lcccccc}
\hline & & & & & Expected \\
& Mean & Std. Dev. & Maximum & Minimum & sign \\
\hline $\begin{array}{l}\text { Price level [PPP/exchange rate ratio] } \\
\text { Log nominal GDP per capita [converted into }\end{array}$ & -0.172 & 0.318 & 0.446 & -1.333 & \\
$\quad$ U.S. \$ at the trading exchange rate] & -0.562 & 0.557 & 0.425 & -2.529 & + \\
$\begin{array}{l}\text { Log trade ratio [ratio of commodity exports } \\
\text { and imports to GDP] }\end{array}$ & 1.218 & 0.518 & 2.416 & -0.374 & - \\
$\begin{array}{l}\text { Log population [million inhabitants] } \\
\text { Log Area [squared kilometers] }\end{array}$ & -2.395 & 1.128 & -0.660 & -4.302 & - \\
$\begin{array}{l}\text { Periphery dummy [indicating if the coun- } \\
\text { try's nominal income represents half or }\end{array}$ & -3.737 & 1.411 & 0.062 & -5.727 & - \\
$\quad$ less the U.S. income] & 0.355 & 0.481 & 1.000 & 0.000 & + \\
$\begin{array}{l}\text { Log net capital inflo [ratio current account } \\
\text { balance, changed sign, to GDP + 1000] }\end{array}$ & 6.916 & 0.033 & 7.131 & 6.864 & + \\
$\begin{array}{l}\text { Alternative monetary regime dummy [taking } \\
\text { value 0 for the Bretton Woods era (1950- }\end{array}$ & & & & & \\
$\quad$ 1970) and value 1 thereafter] & 0.806 & 0.397 & 1.000 & 0.000 & $-/+$ \\
\hline
\end{tabular}

Sources. As in Table 9.

which PPPs exist in the period 1950-1990 (see Table 3), how closely manufacturing wages, which condition tradeable prices, correlate with nominal income, though the association becomes less than proportional as income goes up. ${ }^{31}$ Wages in the tradables' sector really matter because, given internal mobility of labor (and restrictions to external mobility), they also affect wages in nontradable production and, consequently, the price level for non-tradables and, in turn, the aggregate price level. A positive correlation between nominal per capita income and the price level should be expected. Figure 2 supports this hypothesis but the evidence also points to a more than proportional increase in the price level as nominal income rises.

Second, net capital inflo is approximated by the current account balance (with its sign changed), and because a net inflo of capital represents an increase in expenditure while domestic output is held constant, ceteris paribus, the expected relationship should be the larger the net capital inflo , the higher the price level (Clague (1986a)). ${ }^{32}$

Third, the degree of openness, define as the ratio of commodity exports and imports to GDP, is included on the grounds that the variable captures structural change over time. ${ }^{33} \mathrm{~A}$ negative relationship between openness and the price level

31 The evidence for wages refers to earnings per hour in manufacturing industries. The source is ILO Yearbooks for the countries and years covered in Chart 3. The evidence for nominal income is refered in Table 9.

${ }^{32}$ In addition, inward transfers pull labor out of tradables into nontradables, lowering the marginal costs and relative price of commodities (Clague (1986a:321)).

33 Countries more exposed to international trade tend to grow faster (Dollar (1992); Feder (1983); Frankel and Romer (1996); Ben-David and Loewy (1998)). 


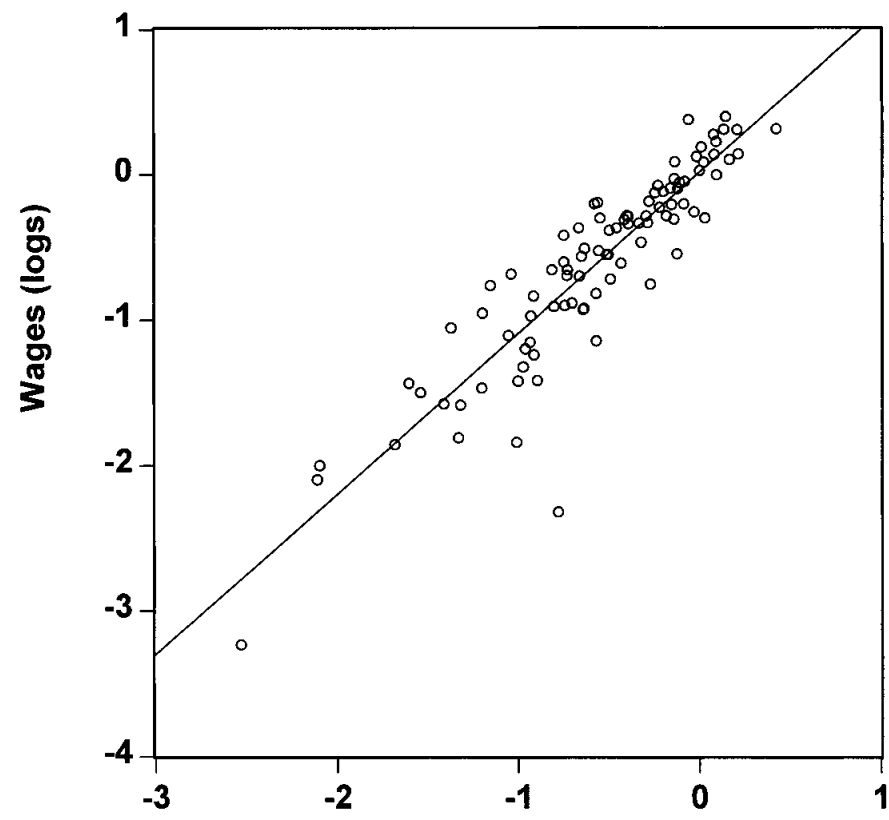

Nominal GDP per head (logs)

FIG. 1. Relative nominal GDP per head and wages, 1950-1990. Countries (and dates) as in Table 3. Sources: Manufacturing earning per hour, ILO Yearbooks. GDP per head, Table 9.

can be predicated (Clague $(1985,1986 \mathrm{a})$ ), although it could be argued that, in addition to equalizing the prices of tradables, trade raises the price of abundant factors and, thus, affects prices of nontradables. ${ }^{34}$ Hence, the direction of the relationship between openness and the price level will depend on whether capital or labor is the relatively abundant factor (Kravis and Lipsey (1987)). Thus, trade in LDCs operates to raise wages for the nontradable sector (that is, the sector which made intensive use of the abundant factor, labor) increasing, consequently, nontradable prices and, in turn, the aggregate price level. Then, a positive rather than a negative association between openness and the price level should be expected. Nonetheless, despite the fact that countries in the European periphery could be depicted as LDCs prior to 1960, it could be argued from the characteristics of the sample of countries included (mainly post-World War II western nations) that the expected relationship would most probably be negative. Since the structural relationship between the PL and the set of independent variables derived from the short-cut method will be applied to out of sample countries and

34 Clague (1988:243) argued that in the specifi factors model the openness variable might have a positive, zero, or negative coefficient in association with the price level depending on whether changes in openness are determined by changes in resource abundance, resource diversity, or tariffs. 
TABLE 3

Available PPPs by Benchmark Years and Country, 1950-1990

\begin{tabular}{|c|c|c|c|c|c|c|c|c|}
\hline & 1950 & 1967 & 1970 & 1973 & 1975 & 1980 & 1985 & 1990 \\
\hline Argentina & & & & & & $\mathrm{x}$ & & \\
\hline Australia & & & & & & & $\mathrm{x}$ & $\mathrm{x}$ \\
\hline Austria & & & & & $\mathrm{x}$ & $\mathrm{x}$ & $\mathrm{x}$ & $\mathrm{x}$ \\
\hline Belgium & $\mathrm{x}$ & & $\mathrm{x}$ & $\mathrm{x}$ & $\mathrm{x}$ & $\mathrm{x}$ & $\mathrm{x}$ & $\mathrm{x}$ \\
\hline Canada & & $\mathrm{x}$ & & & & $\mathrm{x}$ & $\mathrm{x}$ & $\mathrm{x}$ \\
\hline Denmark & $\mathrm{x}$ & & & & $\mathrm{x}$ & $\mathrm{x}$ & $\mathrm{x}$ & $\mathrm{x}$ \\
\hline Finland & & & & & & & $\mathrm{x}$ & $\mathrm{x}$ \\
\hline France & $\mathrm{x}$ & & $\mathrm{x}$ & $\mathrm{x}$ & $\mathrm{x}$ & $\mathrm{x}$ & $\mathrm{x}$ & $\mathrm{x}$ \\
\hline Germany & $\mathrm{x}$ & & $\mathrm{x}$ & $\mathrm{x}$ & $\mathrm{x}$ & $\mathrm{x}$ & $\mathrm{x}$ & $\mathrm{x}$ \\
\hline Greece & & & & & & $\mathrm{x}$ & $\mathrm{x}$ & $\mathrm{x}$ \\
\hline Ireland & & & & & $\mathrm{x}$ & $\mathrm{x}$ & $\mathrm{x}$ & $\mathrm{x}$ \\
\hline Italy & $\mathrm{x}$ & & $\mathrm{x}$ & $\mathrm{x}$ & $\mathrm{x}$ & $\mathrm{x}$ & $\mathrm{x}$ & $\mathrm{x}$ \\
\hline Japan & & $\mathrm{x}$ & $\mathrm{x}$ & $\mathrm{x}$ & $\mathrm{x}$ & $\mathrm{x}$ & $\mathrm{x}$ & $\mathrm{x}$ \\
\hline Netherlands & $\mathrm{x}$ & & $\mathrm{x}$ & $\mathrm{x}$ & $\mathrm{x}$ & $\mathrm{x}$ & $\mathrm{x}$ & $\mathrm{x}$ \\
\hline New Zealand & & & & & & & $\mathrm{x}$ & $\mathrm{x}$ \\
\hline Norway & $\mathrm{x}$ & & & & & $\mathrm{x}$ & $\mathrm{x}$ & $\mathrm{x}$ \\
\hline Portugal & & & & & & $\mathrm{x}$ & $\mathrm{x}$ & $\mathrm{x}$ \\
\hline Spain & & & & & $\mathrm{x}$ & $\mathrm{x}$ & $\mathrm{x}$ & $\mathrm{x}$ \\
\hline Sweden & & & & & & & $\mathrm{x}$ & $\mathrm{x}$ \\
\hline Switzerland & & & & & & & & $\mathrm{x}$ \\
\hline Turkey & & & & & & & $\mathrm{x}$ & $\mathrm{x}$ \\
\hline United Kingdom & $\mathrm{x}$ & $\mathrm{x}$ & $\mathrm{x}$ & $\mathrm{x}$ & $\mathrm{x}$ & $\mathrm{x}$ & $\mathrm{x}$ & $\mathrm{x}$ \\
\hline United States & $\mathrm{x}$ & $\mathrm{x}$ & $\mathrm{x}$ & $\mathrm{x}$ & $\mathrm{x}$ & $\mathrm{x}$ & $\mathrm{x}$ & $\mathrm{x}$ \\
\hline
\end{tabular}

Sources. 1950, Gilbert and associates (1958), Table 5; 1967, Kravis et al. (1975), Tables 13.12 and 13.14; Canada for 1965, from West (1967); 1970-1973, Kravis et al. (1978a), Chap 5; 1975-1990, ICP PPPs in Maddison (1995), Tables C-2 to C-6.

years, it would be wise to allow for a country's relative abundance of labor, that is, for a country being relatively poor, and a way of doing so is to introduce a Periphery dummy variable that takes value one when a country's nominal per capita income is equal to, or less than, half the star country's income, and zero otherwise. ${ }^{35}$ The posited relation between the Periphery dummy and the price level is, for the reasons stated above, a positive one.

Openness is very sensitive to the geographic characteristics of a country, especially to its size, measured either by its physical surface or by its population, and to its distance from potential trading partners (Frankel and Romer (1999)). ${ }^{36}$ An inverse relationship between size and the trade ratio has been often posited. ${ }^{37}$ Lower trade ratios are associated in large countries to the fact that their

35 Alternative specifications in which by Peripheral was meant a country whose income per head ranged between 40 and $60 \%$ of the star country's income, were also tried. The best statistical results (goodness of the fi and robustness to cross-section dummies) were obtained for the 50\% threshold.

36 Lack of historical evidence prevented the inclusion of services in the trade ratio.

37 Perkins and Syrquin (1989), p. 1696, show, for a large sample of countries in 1970, that the trade ratio is negatively correlated with population $(-0.39)$ and total area $(-0.36)$. 


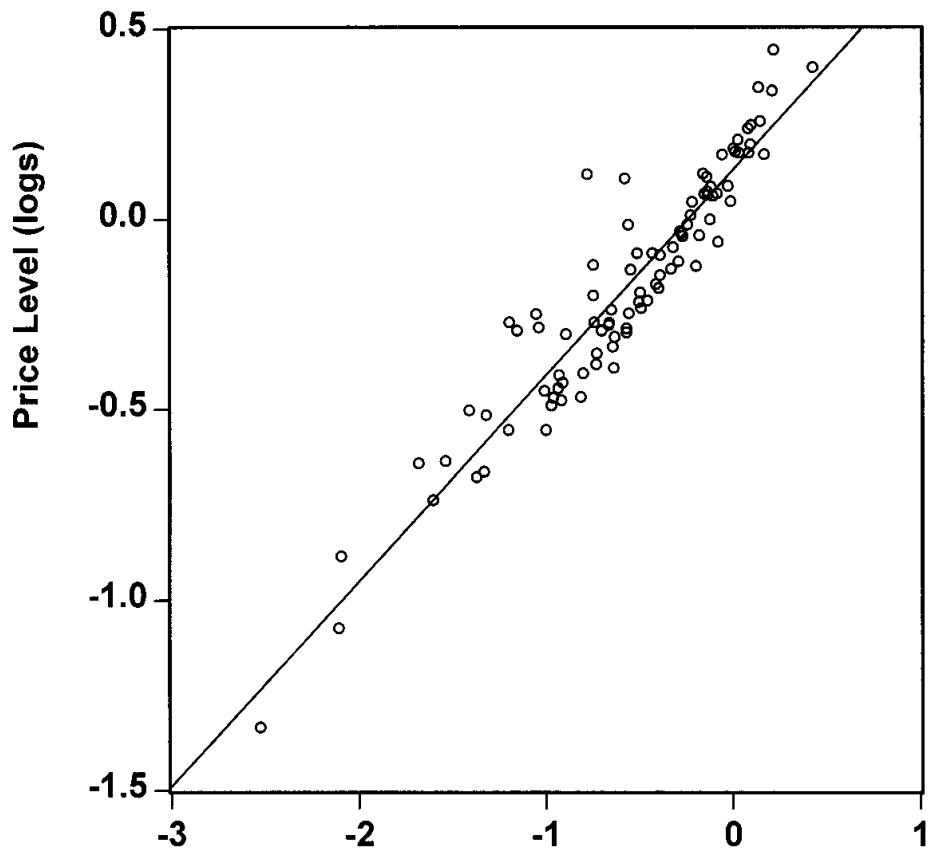

Relative Nominal GDP per head (logs)

FIG. 2. Price level and nominal GDP per head, 1950-1990. Countries (and dates) as in Table 3. Sources: Price level (PPP/ER), PPPs, Table 3; ER, GDP per head, Table 9.

composition of supply matches their demand more closely than in the case of small countries. ${ }^{38}$ In addition, it can be argued that commodity trade ratios to GDP provide a downward biased index of openness over time as the composition of output shifts toward services with economic development (Irwin (1996); Feenstra (1998)). The choice of total aggregate activity (GDP) instead of the less historically accessible commodity output, as denominator in the trade ratio is supported by the fact that the trade ratio is measured here relative to the star country, i.e., the United States. Therefore, the downward time bias in the numerator (each country's trade ratio) is canceled by a similar time bias in the denominator (the U.S. trade ratio). A comprehensive measure of openness is proposed here as the trade ratio corrected for size and relative labor abundance (proxied by the Periphery dummy). ${ }^{39}$ The rationale for the inclusion of size in the short-cut regression is an attempt to correct for the downward bias in a large country's

38 Transport costs, natural resource endowment, economies of scale, and inward-looking strategies all contribute to lower trade ratios in large countries (Perkins and Syrquin (1989)).

39 Lack of data on countries' geographical trade composition prevented including the distance from potential trading partners as an additional variable in the definitio of openness used here. 
openness when measured by the trade ratio. Size is measured both by population and area as the two indicators are not always coincidental (e.g., Japan and Canada). The expected relationship between openness (trade ratio and size) and the national price level is negative. ${ }^{40}$

Lastly, alternative monetary regimes may affect the national price level differently and, thus, a time dummy taking value zero for the Bretton Woods era (1950-1970) and one, thereafter (1970-1990), was also tried. ${ }^{41}$

All available, directly computed Paasche PPPs have been included in the regressions, including calculations for 1950 by Gilbert and associates (1958) and for 1967-1990 by ICP (from rounds I to VI, covering a growing sample of countries, at five-yea intervals, for 1970-1990, together with evidence for 1967 and 1973) (Table 3). ${ }^{42}$ The countries considered include all OECD members for which benchmark estimates were derived, together with Argentina, an "area of new settlement" that completes a group of comparable countries: Australia, New Zealand, and Canada. My choice was to restrict the sample size so that differences in economic organization and culture were kept to a minimum, even though income, climate, and dependence on trade varied significantl across the sample.

Short-cut estimation have been carried out by pooling the data for all crosssections. Thus it allows for changes in the relationship between the price level and nominal per capita income and the rest of explanatory variables over time. ${ }^{43}$ Estimation with panel data techniques has the advantage of increasing the degrees

40 Clague (1988), p. 241, emphasized, however, a positive relationship between country size and the price level if increasing returns to scale are assumed for tradable production but not for nontradable production.

41 The AMR dummy could be seen as a compromise for the out of sample years since from the exchange rate point of view, the Bretton Woods epoch has been associated with the Classical Gold Standard era and the post-Bretton Woods years might be an acceptable aproximation for the Interwar years. Intuitive associations along these lines could be derived from Bordo and Schwartz (1996).

42 The pre-1970 sample could have been enlarged with the detailed extrapolations from 1950 to 1955 by Gilbert and associates (1958) and to 1960 by Kravis (1965) and Denison (1967), independently. Moreover, following Kravis and Lipsey (1987) and Dabán et al. (1997), PPPs could have been estimated for missing years in the 1970-1990 bracket by projecting actual PPPs with the inflatio differential between each country and the United States, following a weak version of the PPP doctrine. Widening the coverage, in particular, for the pre-1970 period would afford the advantage of a more balanced sample of countries over 1950-1990 but with a larger measurement error. I decided to restrict the sample to those countries and years for which PPPs (and, thus, PLs) have been directly computed and not extrapolated. I have carried out, however, the same set of regressions presented in Table 4 for an enlarged sample (including extrapolated PLs for 1955 and 1960) without findin strong discrepancies between them.

43 In the case where the largest set of countries is a priority, choosing the latest and most sophisticated ICP round, as in Maddison (1991, 1995) and Ahmad (1996), may be justified In the present case, this choice is unclear since characteristicity prevails over transitivity and, more important, opting for a single benchmark implies a loss of information given the fact that, from the point of view of indirect estimation of PPPs for earlier periods, all information from different ICP rounds should be considered. As Heston and Summers (1993:359) put it, "we should view the results of successive benchmark comparisons as informing us about the relative positions of the countries throughout the period covered." 
TABLE 4

Regression Results (Estimation Method: GLS (Cross Section Weights))—Dependent Variable: Paasche Price Level (PPP/ER Ratio) (Heteroskedasticity-Consistent Standard Errors and Covariance)

\begin{tabular}{|c|c|c|c|c|c|}
\hline & I & II & III & IV & V \\
\hline Constant & $0.076(0.013)$ & $0.081(0.012)$ & $-3.418(1.290)$ & $-3.000(1.200)$ & $0.095(0.018)$ \\
\hline \multicolumn{6}{|l|}{ Nominal } \\
\hline GDP/head & $0.548(0.012)$ & $0.593(0.015)$ & $0.549(0.012)$ & $0.586(0.015)$ & $0.554(0.012)$ \\
\hline Trade ratio & $-0.118(0.015)$ & $-0.128(0.015)$ & $-0.109(0.015)$ & $-0.115(0.015)$ & $-0.131(0.017)$ \\
\hline Area & $-0.031(0.003)$ & $-0.032(0.004)$ & $-0.029(0.003)$ & $-0.029(0.004)$ & $-0.032(0.003)$ \\
\hline Population & $-0.032(0.007)$ & $-0.036(0.006)$ & $-0.027(0.007)$ & $-0.030(0.006)$ & $-0.037(0.007)$ \\
\hline $\begin{array}{l}\text { Periphery } \\
\text { dummy }\end{array}$ & & $0.063(0.018)$ & & $0.052(0.017)$ & \\
\hline $\begin{array}{l}\text { Net capital } \\
\text { inflo }\end{array}$ & & & $0.506(0.187)$ & $0.446(0.174)$ & \\
\hline $\begin{array}{l}\text { AMR } \\
\text { dummy }\end{array}$ & & & & & $-0.021 *(0.014)$ \\
\hline Observations & 93 & 93 & 93 & 93 & 93 \\
\hline $\begin{array}{l}\text { Adjusted } R^{2} \\
\text { S.E. }\end{array}$ & 0.958 & 0.965 & 0.958 & 0.962 & 0.958 \\
\hline $\begin{array}{l}\text { regression } \\
\text { Durbin-- }\end{array}$ & 0.083 & 0.083 & 0.082 & 0.081 & 0.084 \\
\hline Watson st. & 2.04 & 2.04 & 2.01 & 2.00 & 2.04 \\
\hline$F$-statistic & 523.4 & 507.9 & 418.4 & 384.2 & 425.6 \\
\hline
\end{tabular}

Sources. Dependent variable, as in Table 3; independent variables, as in Table 9.

Notes. * Not significan at 0.10 . Standard errors in brackets. All variables are expressed in natural logarithms and are computed relative to the United States.

of freedom and, therefore, the robustness of the resulting parameters. Finally, the goodness of the fi and the stability and significanc of parameters over different specification were the criteria used to choose the preferred set of equations. Table 4 reports regression results obtained through generalized least squares (GLS) with cross-section weights to control for autocorrelation and heteroskedasticity. ${ }^{44}$

For nominal income and openness (trade ratio and size indicators) a statistically significan association with the price level (either isolated or interacting with each other) was found, positive for nominal income and negative for openness. The Periphery dummy was found statistically significan and positively associated to the PL. Net capital inflo , approximated by the current account balanced with changed sign, showed a positive and significan relation with the national price level, as hypothesized. Finally, the dummy for alternative monetary regimes (AMR) presented a negative correlation, but not statistically significan at 0.10 , with the PL. ${ }^{45}$ All statistically significan variables but net capital inflo proved

${ }^{44}$ Additionally, since variances within cross sections might change over time, White heteroskedasticity consistent covariances were estimated. Alternative regressions without intercept were also tried but the finding in Table 4 were not altered significantl .

45 The natural resource endowment, proxied by hectares of agricultural land per person (data from Hayami and Ruttan (1985) and Prasada Rao (1993)), was also tested as an explanatory variable and 
TABLE 5

Impact on the Price Level of a Change in the Independent

Variables by One Standard Deviation

\begin{tabular}{lrr}
\hline & Equation I & Equation II \\
\hline Nominal GDP per capita & 0.305 & 0.330 \\
Trade ratio & -0.061 & -0.066 \\
Population & -0.036 & -0.041 \\
Area & -0.045 & -0.045 \\
Periphery dummy & & 0.030 \\
\hline
\end{tabular}

Sources. Tables 2 and 4.

robust over time as parameters remain stable and highly significan when a dummy variable for each cross-section was recursively introduced in the short-cut regressions. Net capital inflo was, therefore, omitted and only nominal income, openness (trade ratio and size) and the Periphery dummy were taken into the short-cut method to derive price level estimates.

Price levels (PL) were obtained by applying the parameters obtained from Eq. (II) in Table 4 to the value of each independent variable. I opted for this specificatio as it is not only the best and most robust one but takes on board differences in relative factor endowments, captured in the Periphery dummy, which are a most relevant element for out of sample forecasts. The explanatory power of the independent variables in the best short-cut regressions can be gathered from Table 5. It is worth noticing the dominant impact of nominal income on the PL and the extent to which the impact of the trade ratio is amplifie by the size measures while partly muted in labor-abundant Peripheral economies.

The purpose of the short-cut method, it should be recalled, is to provide conjectures on deviations between PPPs and known ERs, that is, the extent to which national price levels deviate from the U.S. price level. Errors of measurement reside in these deviations. Fortunately, some measure of those errors can be computed when the estimating procedure to derive price levels for nonbenchmark countries is applied to benchmark countries presented in Table 1 and the forecast PL are compared to the ICP directly computed ones (Summers and Heston (1984:218)). In Table 6 measurement errors are provided by the mean absolute deviation (and its standard deviation) from ICP national price levels for alternative estimates. The measurement errors in the new estimates (within 7\%) compare favorably with those observed in earlier data sets. ${ }^{46}$

showed a positive association, but one lacking statistical significance with the price level. However, since arable land is highly correlated with population and physical surface (Perkins and Syrquin (1989)), natural endowments might be captured by the size variable, rendering statistical results nonsignificant Alternative specification in which size variables were excluded did not improve its statistical significance and the variable was discarded.

46 Maddison's deviation for 1990 should be zero by construction (cf. Maddison (1995)) but instead 
TABLE 6

Absolute Measurement Errors in Alternative Datasets [Absolute Deviations from ICP Price Levels]

\begin{tabular}{|c|c|c|c|c|c|c|}
\hline & \multicolumn{2}{|c|}{ Bairoch } & \multicolumn{2}{|c|}{ Maddison (revised) } & \multicolumn{2}{|c|}{ Prados de la Escosura } \\
\hline & Mean & Std. dev. & Mean & Std. dev. & Mean & Std. dev. \\
\hline 1950 & 0.11 & 0.08 & 0.13 & 0.07 & 0.07 & 0.06 \\
\hline 1970 & 0.16 & 0.12 & 0.09 & 0.03 & 0.04 & 0.02 \\
\hline 1975 & 0.32 & 0.16 & 0.04 & 0.03 & 0.05 & 0.03 \\
\hline 1980 & - & - & 0.06 & 0.06 & 0.06 & 0.03 \\
\hline 1985 & - & - & 0.10 & 0.10 & 0.07 & 0.06 \\
\hline 1990 & - & - & 0.04 & 0.08 & 0.07 & 0.07 \\
\hline
\end{tabular}

Sources. Tables 4 and 9.

The main difficulty and potential source of error, however, does not reside in the short-cut approach but in the application of a structural relationship derived from advanced western economies over the past 50 years to earlier and different historical contexts even for the same group of countries. ${ }^{47}$ A way of testing the reliability of out-of-sample inferences derived through the short-cut method is to compare the resulting national price levels to those obtained from direct computations for a remote year, say 1913.

In Table 7, estimates for the aggregate economy are confronted with direct calculations for partial and sectoral aspects of economic activity. Thus, PLs derived from Williamson (1995) refer to basic needs while those obtained from Broadberry $(1994,1997)$ provide PLs from sectors in which tradable goods dominate ouput. ${ }^{48}$ Such a scattered evidence renders the comparison almost impossible. Price levels for food get closer to my indirect PLs for aggregate activity than those constructed from food and rent, while PLs in tradable sectors (as it is mostly the case of agriculture and manufacturing) appear to be higher than my estimates for the whole economy. A more meaningful comparison could be established at least for the U.K. if food and rent PLs were accepted to represent those for nontradable sectors on the grounds that basic necessities constitute the main determinant of wage differences in services and construction, as these are

a $4 \%$ deviation ratio has been detected that perhaps could stem from discrepancies between OECD successive national accounts.

47 Balassa $(1973,1974)$ argued against extrapolating a PPP-trading exchange ratio derived from developed nations to underdeveloped nations on the grounds of their different patterns of development and resource endowment as well as the LDCs' higher government intervention in foreign trade. In the present case, it should be noted that a more homogeneous group of market economies from Europe and the European offshoots (plus Japan) is considered throughout the entire period and that their relative degree of openness is taken into account.

48 Consistency with the choice of the United States as the "star country" for Paasche PLs prevents me from considering a larger range of countries for which PPPs have been computed for agriculture and manufacturing (Dormois and Bardini (1995); Burger (1997); O’Brien and Prados de la Escosura (1992)). 
TABLE 7

Alternative Paasche Price Levels c. 1913 [United States = 1]

\begin{tabular}{|c|c|c|c|c|c|}
\hline Country & $\begin{array}{c}\text { I } \\
\text { GDP } \\
\text { (Prados de la Escosura) }\end{array}$ & $\begin{array}{c}\text { II } \\
\text { Food } \\
\text { (Williamson) }\end{array}$ & $\begin{array}{l}\text { III } \\
\text { Food and rent } \\
\text { (Williamson) }\end{array}$ & $\begin{array}{c}\text { IV } \\
\text { Manufacturing } \\
\text { (Broadberry) }\end{array}$ & $\begin{array}{c}\mathrm{V} \\
\text { Agriculture }^{a} \\
\text { (Broadberry) }\end{array}$ \\
\hline Belgium & 0.791 & 0.700 & 0.593 & & \\
\hline France & 0.837 & 0.870 & 0.765 & & \\
\hline Germany & 0.718 & 0.813 & 0.789 & & \\
\hline Italy & 0.645 & 0.801 & - & & \\
\hline Sweden & 0.752 & 0.781 & 0.849 & & \\
\hline United Kingdom & 0.844 & 0.819 & 0.771 & 0.903 & (1.181) \\
\hline
\end{tabular}

Sources. Column I, derived from Table 9. Columns II-V, computed from Paasche PPPs derived from Williamson (1995) [Cols. II-III]; from Broadberry (1994) [Col. IV]; and from Broadberry (1997) [Col. V (Fisher PPP)].

Notes. Williamson's PPPs, expressed in sterling, have been rebased with the U.S. dollar as reference. Alternative Paasche PPP for manufacturing computed from Burger (1997) gives a PL value of 0.939 .

${ }^{a}$ Fisher PL.

labor intensive activities and productivity differentials are supposed to be narrower there than in the tradable production. Once this assumption is accepted, the price level for the whole economy can be derived just by weighting the sectoral PLs with each sector's share in GDP. The resulting aggregate PL for the United Kingdom amounts to 0.84 (United States $=1.00$ ), a figur identical to the one obtained in Table 7 (Col. I). ${ }^{49}$ The striking coincidence should not translate into overoptimism about the reliability of the short-cut method and its results must be used with caution until systematic testing for a representative group of countries at different benchmarks establishes its reliability. Meanwhile, users of the new estimates of national price levels should remember the warning of Kravis (1984:18) about extrapolations to nonbenchmark countries:

on average, the short-cut estimates ... come closer to the truth than exchange-rate conversions. The difficulty is that the margins of error . . . still create a degree of uncertainty about relationships among individual countries that may be deemed unacceptable for some operational purposes.

\section{THE NEW GDP DATA SET: SOME IMPLICATIONS}

A new set of Laspeyres levels of real product per head at current prices was computed by deflatin levels of nominal GDP per capita (i.e., converted into

49 Using sectoral shares from the 1907 UK Census to weight sectoral PPPs (Table 7), the result is $0.067 \times 1.1807+0.342 \times 0.9025+0.591 \times 0.771=0.843$. When the PL for manufacturing obtained from Burger (1997) is chosen instead, the result is 0.856 . 
dollars through the trading exchange rate) with the estimated Paasche PLs. ${ }^{50}$ Perhaps the best way of drawing some preliminary inferences from the new data set is to compare it against available (PPP-adjusted) GDP estimates produced by Bairoch (1976) in constant 1960 dollars, by Maddison (1995) in 1990 dollars, and with estimates in current dollars derived from trading rates of exchange, the alternative country sets are ordered from the highest to the lowest income level. ${ }^{51}$ Since it could be claimed that the discrepancies across data sets can be attributed in part to the inclusion of improved data in the latest estimates (including Argentina, Austria, Belgium, France, Germany, Greece, Hungary, Ireland, Italy, the Netherlands, Portugal, Spain, and Switzerland), the figure of Maddison (1995) have been revised to incorporate the latest GDP data available, matching the country data used in my new estimates. ${ }^{52}$ Thus, real product per head at current prices (relative to the US) for more than 20 countries over 1820-1990 are displayed in Table 9.

Clearly, country rankings vary according to the data set selected to carry out international comparisons. Yet there are several correlations across data sets that persist over time. Top and bottom countries in the ranking remain roughly the same on all the estimates. High Spearman rank correlations among alternative data sets, if the early $19^{\text {th }}$ century is excluded, support the idea of ranking persistence (Table 8). The favorable position of countries in the "areas of new settlement" and the backward position of countries located along the geographical periphery of Europe (to the south and the east) remain at least till 1950. The advantage of countries in the New World over Europe in the $19^{\text {th }}$ and early $20^{\text {th }}$ centuries suggests that high land-labor ratios prevailed over gains from structural change derived from the firs industrial revolution. The resource-abundant countries benefite from institutional restrictions on trade and factor mobility during the firs half of the $20^{\text {th }}$ century (Nelson and Wright (1992); Broadberry (1997)).

50 This is identical to converting each country' own currency GDP per head into dollars at the PPP exchange rate. See footnote 21 .

51 A previous conversion was required from Geary-Khamis to Paasche PPP converters to transform Maddison's "international" dollars into U.S. dollars, that is, countries' output per head expressed at U.S. relative prices, for 1990. Maddison (1995, Table C-6) provides the appropriate ratios for the conversion. I have chosen to use only Maddison's latest set of figure expressed in U.S. 1990 dollars but his earlier sets (in 1970, 1980, and 1985 U.S. dollars) could also be considered in the comparison (Maddison $(1982,1989,1991)$, and the results would reveal, as already pointed out by O'Rourke and Williamson (1997), significan differences about country rankings due to the fact that each different numeraire (1970 or 1985 U.S. dollars) is linked to a different ICP benchmark and also to Maddison's revision of countries' data. Cf. also Table 1.

${ }^{52}$ Maddison's series have been linked to the new data available for national estimates of real product per head. Most segments replaced in Maddison's series correspond to the $19^{\text {th }}$ century (see Table 9 for details and sources). No attempt has been made, however, to update Bairoch's estimates as they were computed more than two decades ago and only U.S. figure were interpolated for missing years using Maddison (1995). In addition, Bairoch's computation procedures are not expressed in enough detail to allow replication and his data base is quite different from those used both in Maddison (1995) and in my new estimates. 
TABLE 8

Spearman Rank Correlation between Alternative Country Rankings, 1820-1990

\begin{tabular}{lcccc}
\hline & $\begin{array}{c}\text { Prados/ICP- } \\
\text { Exchange Rate }\end{array}$ & $\begin{array}{c}\text { Prados/ICP- } \\
\text { Maddison (R) }\end{array}$ & $\begin{array}{c}\text { Prados/ICP- } \\
\text { Bairoch }\end{array}$ & $\begin{array}{c}\text { Countries } \\
\text { included }\end{array}$ \\
\hline $\begin{array}{l}\text { Pre-World War I borders } \\
1820\end{array}$ & 0.83 & & & \\
1830 & 0.98 & 0.20 & 0.54 & 8 \\
1840 & 0.87 & 0.36 & 0.94 & 9 \\
1850 & 0.93 & 0.69 & 0.86 & 13 \\
1860 & 0.95 & 0.70 & 0.93 & 17 \\
1870 & 0.98 & 0.86 & 0.91 & 19 \\
1880 & 0.98 & 0.78 & 0.93 & 23 \\
1890 & 0.98 & 0.86 & 0.88 & 23 \\
1900 & 0.98 & 0.89 & 0.93 & 23 \\
1913 & 0.98 & 0.89 & 0.94 & 24 \\
Interwar borders & & & & \\
1913 & 0.98 & 0.91 & 0.95 & 27 \\
1929 & 0.99 & 0.92 & 0.92 & 29 \\
1938 & 0.98 & 0.89 & 0.93 & 23 \\
Post-World War II borders & & & & 23 \\
1950 & 0.95 & 0.95 & 0.97 & 23 \\
1960 & 0.99 & 0.91 & 0.96 & 23 \\
1970 & 0.95 & 0.86 & 0.86 & 23 \\
1975 & 0.93 & 0.85 & 0.94 & \\
1980 & 0.90 & 0.91 & & 23 \\
1985 & 0.95 & 0.90 & & \\
1990 & 0.84 & 0.99 & & 23 \\
\hline
\end{tabular}

Sources. Table 9.

Note. ICP directly estimated levels of real product per head substitute for my short-cut estimates whenever available (see Table 3).

Besides, labor-intensive countries in Southern and Eastern Europe remained relatively backward while the internal differential between south and east appears to be relatively stable over the long run.

But what differences can be observed between the new and the older estimates? In the firs place, U.S. leadership seems to have emerged earlier. Measured in per capita income (adjusted for its purchasing power) and at current prices, America was already ahead of the western world, Australia excluded, by 1880. Furthermore, the overall superiority of areas of new settlement is less discernable even though their privileged position is still there. Thus, U.S. comparative advantage based upon an intensive use of natural resources (Wright (1990)) together with shifts of resources away from agriculture (Broadberry (1997)) seem to be the clues for the United States overtaking the UK. The endogenous nature of U.S. natural resource endowment (David and Wright (1997)) and its large market scale help to explain American success among resource-abundant countries and with respect to Europe (Abramovitz and David (1996)). This findin is congruent with Bairoch's numbers for the post-1880 period, but is at odds with Maddison's 
figure which show the United States behind the United Kingdom (and Australia and New Zealand) until the eve of World War I.

My new estimates suggest that while the United Kingdom had already fallen behind the United States by 1880 its relative position was, in turn, closer to that of France. In the late 19th century, French product per head moved from $17 \%$ below the U.K. level in 1880 to a differential of a mere $9 \%$ on the eve of World War I, when its real income stood still above the German level. The estimates question more pessimistic figure offered by Bairoch, Crafts (1984a), and Maddison and provides qualifie support for the revisionistic picture of two distinct but comparable paths to $20^{\text {th }}$ century drawn by O'Brien and Keyder (1978). ${ }^{53}$ Despite the upward adjustment of $19^{\text {th }}$ century Germany's income level (introduced to allow for the fact that German national accounts are expressed net and not gross) this country does not retain the relative per capita income to the United States shown in Maddison's data set. ${ }^{54}$ Germany does display, however, a clearer tendency to catch up with the United Kingdom than in earlier estimates (including those of Crafts (1983) and Fremdling (1991)). Its per capita income rises from about 60\% of U.K. income in mid- $19^{\text {th }}$ century to $12 \%$ below British real product per head by 1913.

It is not clear, according to the new evidence, that the club of 16/17 Core countries on which Maddison $(1991,1995)$ focuses existed prior to World War II. If a wider and more geographical definitio of Peripheral countries than usual is accepted, it appears that differences between Scandinavian and Latin countries emerged during the late $19^{\text {th }}$ century (O'Rourke and Williamson (1997)). By mid- $19^{\text {th }}$ century differences in real income between Scandinavian and Latin or Central European countries were narrow. A widening gap between Scandinavia and southern Europe appeared by the turn of the century with Norway and Sweden catching up with an enlarging Core. On the eve of the Great Depression only Finland and Italy were still part of the Periphery among Maddison's advanced 17 and it was not until the 1960s that the European Periphery as we know it today was settled.

As they stand, the differences between new and earlier real income estimates are accounted for by the variations in price levels. My new data set suggests that, relative to the United States, $19^{\text {th }}$ century price levels in Australia and New Zealand, in the U.K., and in Belgium and the Netherlands were, in fact, higher than those implicitly assumed in Maddison's well-known estimates. This observation raises the central question explored in this paper: which of the several data sets currently available for purposes of international comparisons of productivity levels and standards of living is the most reliable? The answer must reside to a

53 It must be acknowledged, however, that the new GDP estimates by Toutain (1997) do contribute to the French improvement substantially, though they are already included in Maddison (1995).

${ }^{54}$ It should be borne in mind that in my new estimates Germany refers to the whole country, based on nominal income at current prices, whereas constant price estimates expressed in present-time dollars start from West German levels of per capita income, whatever adjustments are performed to the series later. 
TABLE 9

Relative GDP per Head, 1820-1990: Alternative Estimates [United States = 1]

\begin{tabular}{ll}
\hline \multicolumn{2}{c}{ Prados de la Escosura } \\
1 Australia & 1022 \\
2 USA & 1000 \\
3 UK & 0965 \\
4 Netherlands & 0800 \\
5 France & 0713 \\
6 Denmark & 0513
\end{tabular}

Relative GDP per head in 1820 (pre-World War I borders)

\begin{tabular}{lll}
\multicolumn{3}{c}{ Maddison (R) } \\
1 Netherlands & 1670 \\
2 UK & 1437 \\
3 Australia & 1316 \\
4 Denmark & 1282 \\
5 USA & 1000 \\
6 France & 0829
\end{tabular}

Exchange Rate

$\begin{array}{ll}1 \text { Australia } & 1361 \\ 2 \text { UK } & 1228 \\ 3 \text { USA } & 1000 \\ 4 \text { Netherlands } & 0959 \\ 5 \text { France } & 0690 \\ 6 \text { Denmark } & 0548\end{array}$

Relative GDP per head in 1830 (pre-World War I borders)

Prados de la Escosura

1 Australia

2 UK

3 USA

4 France

5 Netherlands

6 Sweden

7 Denmark

8 Austria
Prados de la Escosura

1 Australia

2 USA

3 UK

4 Netherlands

5 France

6 Belgium

7 Sweden

8 Denmark

9 Austria

Prados de la Escosura

1 Australia

2 UK

3 USA

4 Canada

6 France

7 Belgium

8 Denmark

9 Spain

10 Germany

11 Austria

12 Sweden

13 Portugal
1174

1004

1000

0784

0768

0663

0584

0551
1370

1000

0975

0814

0790

0749

0676

0616

0554
Maddison (R)

1 Netherlands

2 UK

3 Austria

4 Denmark

5 USA

6 France

7 Sweden

Relative GDP per head in 1840 (pre-World War I borders)

\begin{tabular}{|c|c|c|}
\hline \multicolumn{2}{|c|}{ Maddison (R) } & Bairc \\
\hline 1 Netherlands & 1369 & 1 USA \\
\hline 2 UK & 1354 & $2 \mathrm{UK}$ \\
\hline 3 Belgium & 1194 & 3 Netherlands \\
\hline 4 Austria & 1156 & 4 Belgium \\
\hline USA & 1000 & 5 France \\
\hline Denmark & 0971 & 6 Denmark \\
\hline France & 0885 & 7 Sweden \\
\hline Sweden & 0635 & \\
\hline
\end{tabular}

Relative GDP per head in 1850 (pre-World War I borders)

Maddison (R)

$1096 \quad 1$ Australia

1000

1000

0827

0791

0781

0742

0661

0638

0609

0541

0520

0456

2 UK

3 Netherlands

4 Belgium

5 Austria

6 Denmark

7 USA

8 France

9 Germany

10 Canada

11 Spain

12 Sweden

1424
1404

1253

1089

1000

0831

$\begin{array}{ll}1 & \text { USA } \\ 2 & \text { Netherlands }\end{array}$

4 Australia

5 France

6 Denmark

7 Sweden

Bairoch
5 Netherlands

13 Portugal

Relative GDP per head in 1860 (pre-World War I borders)

Prados de la Escosura

1 Australia

2 New Zealand

3 USA

4 UK

5 Canada

6 France

7 Belgium

8 Netherlands

9 Germany

10 Italy

11 Spain

12 Denmark

13 Sweden

14 Austria

15 Portugal

16 Greece

17 Finland

\section{Maddison (R)}

$1304 \quad 1$ Australia

11212 New Zealand

$1000 \quad 3$ UK

09714 Belgium

08345 Netherlands

0821

0792

0766

0681

0641

0638

0626

0553

0518

0469

0405

0381
6 USA

7 Austria

8 Denmark

9 Greece

10 France

11 Germany

12 Italy

13 Canada

14 Spain

15 Sweden

16 Finland

17 Portugal

1000
0970
0941
0850
0744
0554
0488

000

970

941
050

744

0488

1000
9664

0961

0733

578

539

8$$
8
$$

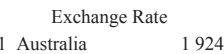

2 UK 1287

3 USA 1000

4 Netherlands $\quad 0856$

5 France $\quad 0848$

6 Sweden $\quad 0789$

7 Denmark 0530

8 Austria $\quad 0418$

Exchange Rate

1 Australia 2420

2 UK 1142

3 USA 1000

4 Belgium 0925

5 France 0834

6 Sweden 0825

7 Netherlands $\quad 0824$

8 Denmark 0549

9 Austria $\quad 0416$

Exchange Rate

\begin{tabular}{llrlll}
\multicolumn{3}{c}{ Bairoch } & \multicolumn{3}{c}{ Exchange Rate } \\
1903 & 1 USA & 1000 & 1 Australia & 1540 \\
1392 & 2 UK & 0996 & 2 UK & 1299 \\
1372 & 3 Netherlands & 0928 & 3 USA & 1000 \\
1203 & 4 Belgium & 0894 & 4 Belgium & 0889 \\
1119 & 5 France & 0724 & 5 France & 0840 \\
1097 & 6 Spain & 0681 & 6 Netherlands & 0796 \\
1000 & 7 Germany & 0670 & 7 Canada & 0770 \\
0865 & 8 Portugal & 0565 & 8 Spain & 0656 \\
0853 & 9 Denmark & 0557 & 9 Denmark & 0655 \\
0783 & 10 Sweden & 0459 & 10 Germany & 0473 \\
0700 & & & 11 Sweden & 0442 \\
0631 & & & 12 Austria & 0441 \\
0488 & & & 13 Portugal & 0320
\end{tabular}

Exchange Rate

$1165 \quad 1$ New Zealand 2899

$1008 \quad 2$ Australia $\quad 2219$

$1000 \quad 3$ UK 1150

$\begin{array}{lll}0885 & 4 \text { Belgium } & 1073\end{array}$

$\begin{array}{lll}0816 & 5 \text { USA } & 1000 \\ 0749 & 6 \text { France } & 0896\end{array}$

$0656 \quad 7$ Canada $\quad 0822$

$0639 \quad 8$ Netherlands $\quad 0698$

06259 Spain 0666

054410 Denmark $\quad 0656$

$0531 \quad 11$ Italy 0571

$0497 \quad 12$ Germany 0543

043513 Sweden 0492

$0415 \quad 14$ Austria $\quad 0384$

040615 Portugal 0343

16 Greece 0239

17 Finland $\quad 0214$ 


\begin{tabular}{|c|c|c|c|c|c|c|c|}
\hline \multicolumn{8}{|c|}{ Relative GDP per head in 1870 (pre-World War I borders) } \\
\hline \multicolumn{2}{|c|}{ Prados de la Escosura } & \multicolumn{2}{|c|}{ Maddison (R) } & \multicolumn{2}{|l|}{ Bairoch } & \multicolumn{2}{|c|}{ Exchange Rate } \\
\hline 1 Australia & 1130 & 1 Australia & 1630 & $1 \mathrm{UK}$ & 1011 & 1 New Zealand & 1850 \\
\hline 2 New Zealand & 1100 & 2 New Zealand & 1548 & 2 USA & 1000 & 2 Australia & 1395 \\
\hline $3 \mathrm{UK}$ & 1004 & 3 Belgium & 1444 & 3 Belgium & 0919 & $3 \mathrm{UK}$ & 1038 \\
\hline 4 USA & 1000 & $4 \mathrm{UK}$ & 1422 & 4 Netherlands & 0815 & 4 USA & 1000 \\
\hline 5 Belgium & 0836 & 5 Netherlands & 1115 & 5 France & 0703 & 5 Belgium & 0995 \\
\hline 6 Canada & 0828 & 6 USA & 1000 & 6 Germany & 0686 & 6 France & 0698 \\
\hline 7 France & 0809 & 7 Austria & 0954 & 7 Norway & 0678 & 7 Canada & 0619 \\
\hline 8 Netherlands & 0787 & 8 Denmark & 0860 & 8 Denmark & 0547 & 8 Netherlands & 0595 \\
\hline 9 Germany & 0679 & 9 France & 0750 & 9 Spain & 0530 & 9 Denmark & 0592 \\
\hline 10 Denmark & 0659 & 10 Germany & 0701 & 10 Finland & 0504 & 10 Norway & 0493 \\
\hline 11 Norway & 0608 & 11 Canada & 0687 & 11 Italy & 0502 & 11 Germany & 0459 \\
\hline 12 Italy & 0589 & 12 Greece & 0666 & 12 Austria-Hungary & 0491 & 12 Spain & 0451 \\
\hline 13 Austria & 0575 & 13 Italy & 0647 & 13 Portugal & 0435 & 13 Italy & 0441 \\
\hline 14 Sweden & 0558 & 14 Sweden & 0577 & 14 Greece & 0402 & 14 Sweden & 0377 \\
\hline 15 Spain & 0554 & 15 Norway & 0541 & 15 Sweden & 0396 & 15 Austria & 0365 \\
\hline 16 Portugal & 0460 & 16 Spain & 0538 & & & 16 Portugal & 0282 \\
\hline 17 Finland & 0446 & 17 Finland & 0477 & & & 17 Finland & 0233 \\
\hline 18 Hungary & 0441 & 18 Hungary & 0396 & & & 18 Hungary & 0200 \\
\hline 19 Greece & 0392 & 19 Portugal & 0373 & & & 19 Greece & 0179 \\
\hline \multicolumn{8}{|c|}{ Relative GDP per head in 1880 (pre-World War I borders) } \\
\hline \multicolumn{2}{|c|}{ Prados de la Escosura } & \multicolumn{2}{|c|}{ Maddison (R) } & \multicolumn{2}{|l|}{ Bairoch } & \multicolumn{2}{|c|}{ Exchange Rate } \\
\hline 1 Australia & 1049 & 1 Australia & 1521 & 1 USA & 1000 & 1 New Zealand & 1320 \\
\hline 2 USA & 1000 & 2 New Zealand & 1316 & $2 \mathrm{UK}$ & 0842 & 2 Australia & 1315 \\
\hline $3 \mathrm{UK}$ & 0903 & 3 Belgium & 1193 & 3 Switzerland & 0837 & 3 USA & 1000 \\
\hline 4 New Zealand & 0895 & $4 \mathrm{UK}$ & 1190 & 4 Belgium & 0730 & $4 \mathrm{UK}$ & 0872 \\
\hline 5 Belgium & 0793 & 5 USA & 1000 & 5 Netherlands & 0671 & 5 Belgium & 0857 \\
\hline 6 France & 0753 & 6 Netherlands & 0951 & 6 France & 0575 & 6 France & 0588 \\
\hline 7 Canada & 0740 & 7 Austria & 0761 & 7 Norway & 0575 & 7 Switzerland & 0549 \\
\hline 8 Argentina & 0734 & 8 Denmark & 0724 & 8 Germany & 0549 & 8 Argentina & 0536 \\
\hline 9 Netherlands & 0708 & 9 Germany & 0697 & 9 Denmark & 0491 & 9 Canada & 0525 \\
\hline 10 Switzerland & 0687 & 10 Greece & 0664 & 10 Finland & 0405 & 10 Netherlands & 0531 \\
\hline 11 Germany & 0620 & 11 France & 0660 & 11 Spain & 0400 & 11 Denmark & 0518 \\
\hline 12 Denmark & 0618 & 12 Argentina & 0559 & 12 Austria-Hungary & 0390 & 12 Spain & 0488 \\
\hline 13 Norway & 0569 & 13 Spain & 0575 & 13 Italy & 0385 & 13 Norway & 0456 \\
\hline 14 Spain & 0564 & 14 Canada & 0573 & 14 Sweden & 0375 & 14 Germany & 0426 \\
\hline 15 Sweden & 0542 & 15 Italy & 0527 & 15 Portugal & 0334 & 15 Italy & 0386 \\
\hline 16 Italy & 0535 & 16 Sweden & 0500 & 16 Greece & 0322 & 16 Sweden & 0361 \\
\hline 17 Austria & 0523 & 17 Norway & 0466 & 17 Russia & 0277 & 17 Austria & 0335 \\
\hline 18 Hungary & 0429 & 18 Finland & 0374 & & & 18 Portugal & 0256 \\
\hline 19 Portugal & 0428 & 19 Hungary & 0367 & & & 19 Hungary & 0200 \\
\hline 20 Finland & 0426 & 20 Portugal & 0307 & & & 20 Finland & 0198 \\
\hline 21 Russia & 0410 & 21 Russia & 0298 & & & 21 Greece & 0187 \\
\hline 22 Greece & 0379 & 22 Japan & 0278 & & & 22 Russia & 0136 \\
\hline 23 Japan & 0265 & & & & & 23 Japan & 0081 \\
\hline \multicolumn{8}{|c|}{ Relative GDP per head in 1890 (pre-World War I borders) } \\
\hline \multicolumn{2}{|c|}{ Prados de la Escosura } & \multicolumn{2}{|c|}{ Maddison (R) } & Bairoch & & Exchange & \\
\hline 1 Australia & 1085 & 1 Australia & 1482 & 1 USA & 1000 & 1 Australia & 1476 \\
\hline 2 USA & 1000 & 2 New Zealand & 1210 & $2 \mathrm{UK}$ & 0914 & 2 New Zealand & 1124 \\
\hline $3 \mathrm{UK}$ & 0915 & 3 Belgium & 1175 & 3 Switzerland & 0821 & 3 USA & 1000 \\
\hline 4 New Zealand & 0870 & $4 \mathrm{UK}$ & 1169 & 4 Belgium & 0734 & $4 \mathrm{UK}$ & 0884 \\
\hline 5 Canada & 0809 & 5 Netherlands & 1002 & 5 Netherlands & 0682 & 5 Belgium & 0825 \\
\hline 6 Belgium & 0791 & 6 USA & 1000 & 6 Germany & 0625 & 6 Canada & 0694 \\
\hline 7 France & 0784 & 7 Argentina & 0873 & 7 Norway & 0609 & 7 France & 0679 \\
\hline 8 Argentina & 0782 & 8 Germany & 0829 & 8 France & 0600 & 8 Switzerland & 0615 \\
\hline 9 Germany & 0738 & 9 Denmark & 0784 & 9 Denmark & 0585 & 9 Argentina & 0594 \\
\hline 10 Netherlands & 0735 & 10 Austria & 0782 & 10 Finland & 0429 & 10 Germany & 0561 \\
\hline 11 Switzerland & 0726 & 11 France & 0698 & 11 Austria-Hungary & 0420 & 11 Denmark & 0557 \\
\hline 12 Denmark & 0644 & 12 Canada & 0689 & 12 Sweden & 0415 & 12 Netherlands & 0551 \\
\hline 13 Norway & 0603 & 13 Greece & 0534 & 13 Spain & 0374 & 13 Norway & 0490 \\
\hline 14 Sweden & 0580 & 14 Spain & 0534 & 14 Italy & 0362 & 14 Spain & 0448 \\
\hline 15 Spain & 0567 & 15 Sweden & 0531 & 15 Greece & 0338 & 15 Sweden & 0398 \\
\hline 16 Austria & 0543 & 16 Italy & 0521 & 16 Portugal & 0314 & 16 Italy & 0379 \\
\hline 17 Italy & 0525 & 17 Norway & 0492 & 17 Russia & 0212 & 17 Austria & 0363 \\
\hline
\end{tabular}


TABLE 9-Continued

\begin{tabular}{llllll}
\hline 18 Hungary & 0469 & 18 Hungary & 0449 & 18 Portugal \\
19 Portugal & 0452 & 19 Finland & 0420 & 19 Hungary & 0291 \\
20 Russia & 0445 & 20 Portugal & 0340 & 259 \\
21 Finland & 0435 & 21 Japan & 0298 & 21 Greece \\
22 Greece & 0378 & 22 Russia & 0280 & 22 Russia & 0180 \\
23 Japan & 0307 & & & 23 Japan & 0162
\end{tabular}

Relative GDP per head in 1900 (pre-World War I borders)

\begin{tabular}{llllll}
\multicolumn{1}{c}{ Prados de la Escosura } & \multicolumn{1}{c}{ Maddison (R) } & Bairoch \\
1 USA & 1000 & 1 New Zealand & 1147 & 1 USA \\
2 Australia & 0976 & 2 Australia & 1121 & 2 UK \\
3 UK & 0917 & 3 UK & 1100 & 3 Switzerland \\
4 New Zealand & 0866 & 4 Belgium & 1031 & 4 Belgium \\
5 Canada & 0853 & 5 USA & 1000 & 5 Germany \\
6 Belgium & 0772 & 6 Switzerland & 0920 & 6 Denmark \\
7 France & 0768 & 7 Netherlands & 0906 & 7 Netherlands \\
8 Argentina & 0762 & 8 Argentina & 0829 & 8 France \\
9 Germany & 0753 & 9 Germany & 0810 & 9 Norway \\
10 Switzerland & 0741 & 10 Denmark & 0788 & 10 Sweden \\
11 Netherlands & 0715 & 11 Austria & 0733 & 11 Finland \\
12 Norway & 0670 & 12 France & 0720 & 12 Austria-Hungary \\
13 Denmark & 0668 & 13 Canada & 0720 & 13 Spain \\
14 Sweden & 0622 & 14 Sweden & 0575 & 14 Italy \\
15 Austria & 0531 & 15 Spain & 0529 & 15 Greece \\
16 Spain & 0521 & 16 Italy & 0468 & 16 Portugal \\
17 Italy & 0512 & 17 Norway & 0453 & 17 Russia \\
18 Finland & 0492 & 18 Hungary & 0437 & \\
19 Hungary & 0461 & 19 Finland & 0427 & \\
20 Russia & 0452 & 20 Greece & 0420 & \\
21 Portugal & 0410 & 21 Russia & 0324 & \\
22 Japan & 0335 & 22 Japan & 0307 & \\
23 Greece & 0306 & 23 Portugal & 0290 &
\end{tabular}

\begin{tabular}{lll}
\multicolumn{3}{c}{ Exchange Rate } \\
1000 & 1 New Zealand & 1060 \\
0851 & 2 USA & 1000 \\
0758 & 3 Australia & 0993 \\
0696 & 4 UK & 0923 \\
0617 & 5 Belgium & 0744 \\
0611 & 6 Canada & 0724 \\
0593 & 7 Switzerland & 0691 \\
0583 & 8 France & 0666 \\
0557 & 9 Argentina & 0596 \\
0438 & 10 Germany & 0588 \\
0410 & 11 Denmark & 0594 \\
0400 & 12 Norway & 0546 \\
0339 & 13 Netherlands & 0502 \\
0323 & 14 Sweden & 0497 \\
0290 & 15 Spain & 0348 \\
0277 & 16 Italy & 0341 \\
0239 & 17 Austria & 0341 \\
& 18 Finland & 0284 \\
& 19 Hungary & 0251 \\
& 20 Portugal & 0219 \\
& 21 Russia & 0184 \\
& 22 Japan & 0111 \\
& 23 Greece & 0105
\end{tabular}

Relative GDP per head in 1913 (pre-World War I borders)

Prados de la Escosura

$\begin{array}{llllll}1 \text { USA } & 1000 & 1 \text { Australia } & 1125 & 1 \text { USA } \\ 2 \text { Australia } & 0976 & 2 \text { Argentina } & 1086 & 2 \text { Canada } \\ 3 \text { Canada } & 0968 & 3 \text { New Zealand } & 1069 & 3 \text { Australia } \\ 4 \text { UK } & 0847 & 4 \text { USA } & 1000 & 4 \text { UK } \\ 5 \text { New Zealand } & 0838 & 5 \text { Belgium } & 0966 & 5 \text { Switzerland } \\ 6 \text { Argentina } & 0813 & 6 \text { UK } & 0961 & 6 \text { Belgium } \\ 7 \text { France } & 0770 & 7 \text { Canada } & 0865 & 7 \text { Denmark } \\ 8 \text { Belgium } & 0743 & 8 \text { Switzerland } & 0859 & 8 \text { New Zealand } \\ 9 \text { Germany } & 0742 & 9 \text { Netherlands } & 0830 & 9 \text { Germany } \\ 10 \text { Switzerland } & 0726 & 10 \text { Denmark } & 0800 & 10 \text { Netherlands } \\ 11 \text { Norway } & 0683 & 11 \text { Germany } & 0754 & 11 \text { Norway } \\ 12 \text { Denmark } & 0677 & 12 \text { Austria } & 0704 & 12 \text { France } \\ 13 \text { Sweden } & 0673 & 13 \text { France } & 0687 & 13 \text { Austria-Hungary } \\ 14 \text { Netherlands } & 0668 & 14 \text { Sweden } & 0632 & 14 \text { Sweden } \\ 15 \text { Austria } & 0532 & 15 \text { Greece } & 0539 & 15 \text { Ireland } \\ 16 \text { Italy } & 0526 & 16 \text { Italy } & 0527 & 16 \text { Finland } \\ 17 \text { Spain } & 0511 & 17 \text { Norway } & 0463 & 17 \text { Italy } \\ 18 \text { Finland } & 0490 & 18 \text { Spain } & 0442 & 18 \text { Spain } \\ 19 \text { Hungary } & 0461 & 19 \text { Finland } & 0424 & 19 \text { Russia } \\ 20 \text { Russia } & 0451 & 20 \text { Hungary } & 0424 & 20 \text { Greece } \\ 21 \text { Portugal } & 0396 & 21 \text { Bulgaria } & 0302 & 21 \text { Portugal } \\ 22 \text { Greece } & 0391 & 22 \text { Russia } & 0300 & 22 \text { Bulgaria } \\ 23 \text { Japan } & 0375 & 23 \text { Japan } & 0269 & 23 \text { Japan } \\ 24 \text { Bulgaria } & 0369 & 24 \text { Portugal } & 0239 & \end{array}$

Bairoch

Exchange Rate

\begin{tabular}{|c|c|c|}
\hline 1000 & 1 Australia & 1063 \\
\hline 0835 & 2 USA & 1000 \\
\hline 0754 & 3 Canada & 0971 \\
\hline 0707 & 4 New Zealand & 0966 \\
\hline 0705 & 5 UK & 0715 \\
\hline 0655 & 6 Switzerland & 0662 \\
\hline 0632 & 7 France & 0645 \\
\hline 0586 & 8 Argentina & 0633 \\
\hline 0555 & 9 Belgium & 0588 \\
\hline 0552 & 10 Denmark & 0583 \\
\hline 0549 & 11 Norway & 0544 \\
\hline 0509 & 12 Germany & 0529 \\
\hline 0499 & 13 Sweden & 0507 \\
\hline 0498 & 14 Netherlands & 0438 \\
\hline 0448 & 15 Austria & 0352 \\
\hline 0381 & 16 Italy & 0339 \\
\hline 0232 & 17 Spain & 0332 \\
\hline 0269 & 18 Finland & 0267 \\
\hline 0239 & 19 Hungary & 0261 \\
\hline 0236 & 20 Bulgaria & 0220 \\
\hline 0214 & 21 Greece & 0202 \\
\hline 0193 & 22 Portugal & 0200 \\
\hline \multirow[t]{2}{*}{0185} & 23 Russia & 0173 \\
\hline & 24 Japan & 0131 \\
\hline
\end{tabular}

Relative GDP per head in 1913 (interwar borders)

Prados de la Escosura

Maddison ( $\mathrm{R}$ )

Bairoch

Exchange Rate

$\begin{array}{lllllllll}1 \text { USA } & 1000 & 1 \text { Australia } & 1125 & 1 \text { USA } & 1000 & 1 \text { Australia } & 1063 \\ 2 \text { Australia } & 0976 & 2 \text { Argentina } & 1086 & 2 \text { Canada } & 0835 & 2 \text { USA } & 1000 \\ 3 \text { Canada } & 0968 & 3 \text { New Zealand } & 1069 & 3 \text { Australia } & 0754 & 3 \text { Canada } & 0971 \\ 4 \text { UK } & 0850 & 4 \text { USA } & 1000 & 4 \text { UK } & 0730 & 4 \text { New Zealand } & 0966 \\ 5 \text { New Zealand } & 0838 & 5 \text { UK } & 0991 & 5 \text { Switzerland } & 0705 & 5 \text { UK }\end{array}$


TABLE 9-Continued

\begin{tabular}{|c|c|c|c|c|c|c|c|}
\hline 6 Argentina & 0813 & 6 Belgium & 0966 & 6 Belgium & 0655 & 6 Switzerland & 0662 \\
\hline 7 France & 0770 & 7 Canada & 0865 & 7 Denmark & 0632 & 7 France & 0645 \\
\hline 8 Belgium & 0743 & 8 Switzerland & 0859 & 8 New Zealand & 0586 & 8 Argentina & 0633 \\
\hline 9 Germany & 0742 & 9 Netherlands & 0830 & 9 Germany & 0555 & 9 Belgium & 0588 \\
\hline 10 Switzerland & 0726 & 10 Denmark & 0800 & 10 Netherlands & 0552 & 10 Denmark & 0583 \\
\hline 11 Norway & 0683 & 11 Germany & 0754 & 11 Norway & 0549 & 11 Norway & 0544 \\
\hline 12 Denmark & 0677 & 12 Austria & 0704 & 12 France & 0509 & 12 Germany & 0529 \\
\hline 13 Sweden & 0673 & 13 France & 0687 & 13 Sweden & 0498 & 13 Sweden & 0507 \\
\hline 14 Netherlands & 0668 & 14 Sweden & 0632 & 14 Ireland & 0448 & 14 Austria & 0474 \\
\hline 15 Austria & 0560 & 15 Ireland & 0547 & 15 Czechoslovakia & 0384 & 15 Netherlands & 0438 \\
\hline 16 Italy & 0526 & 16 Greece & 0539 & 16 Finland & 0381 & 16 Italy & 0339 \\
\hline 17 Ireland & 0516 & 17 Italy & 0527 & 17 Italy & 0323 & 17 Spain & 0332 \\
\hline 18 Spain & 0511 & 18 Norway & 0463 & 18 Hungary & 0273 & 18 Czechoslovakia & 0312 \\
\hline 19 Czechoslovakia & 0492 & 19 Spain & 0442 & 19 Spain & 0269 & 19 Ireland & 0277 \\
\hline 20 Finland & 0490 & 20 Finland & 0424 & 20 Greece & 0236 & 20 Finland & 0267 \\
\hline 21 Hungary & 0419 & 21 Hungary & 0424 & 21 Portugal & 0214 & 21 Hungary & 0240 \\
\hline 22 Romania & 0407 & 22 Czechoslovakia & 0423 & 22 Bulgaria & 0193 & 22 Bulgaria & 0220 \\
\hline 23 Portugal & 0396 & 23 Bulgaria & 0302 & 23 Japan & 0185 & 23 Greece & 0202 \\
\hline 24 Greece & 0391 & 24 Japan & 0269 & & & 24 Romania & 0201 \\
\hline 25 Japan & 0375 & 25 Portugal & 0239 & & & 25 Portugal & 0200 \\
\hline 26 Bulgaria & 0369 & 26 Turkey & 0236 & & & 26 Japan & 0131 \\
\hline 27 Turkey & 0353 & & & & & 27 Turkey & 0122 \\
\hline
\end{tabular}

Relative GDP per head in 1929 (interwar borders)

\begin{tabular}{|c|c|c|c|c|c|c|c|}
\hline \multicolumn{2}{|c|}{ Prados de la Escosura } & \multicolumn{2}{|c|}{ Maddison (R) } & \multicolumn{2}{|l|}{ Bairoch } & \multicolumn{2}{|c|}{ Exchange Rate } \\
\hline 1 USA & 1000 & 1 USA & 1000 & 1 USA & 1000 & 1 USA & 1000 \\
\hline 2 Canada & 0900 & 2 Switzerland & 0989 & 2 Canada & 0712 & 2 Australia & 0760 \\
\hline 3 Australia & 0860 & 3 Netherlands & 0905 & 3 Switzerland & 0707 & 3 Canada & 0748 \\
\hline 4 UK & 0774 & 4 New Zealand & 0843 & 4 Belgium & 0613 & 4 New Zealand & 0668 \\
\hline 5 New Zealand & 0757 & 5 Australia & 0807 & 5 New Zealand & 0587 & $5 \mathrm{UK}$ & 0594 \\
\hline 6 Switzerland & 0674 & 6 Denmark & 0805 & $6 \mathrm{UK}$ & 0580 & 6 Switzerland & 0571 \\
\hline 7 Denmark & 0662 & 7 Argentina & 0800 & 7 Norway & 0577 & 7 Denmark & 0520 \\
\hline 8 Argentina & 0648 & 8 Canada & 0793 & 8 Netherlands & 0563 & 8 Norway & 0490 \\
\hline 9 Sweden & 0626 & $9 \mathrm{UK}$ & 0784 & 9 France & 0549 & 9 Sweden & 0476 \\
\hline Norway & 0615 & 10 Belgium & 0753 & 10 Australia & 0542 & 10 Argentina & 0415 \\
\hline Germany & 0607 & 11 France & 0738 & 11 Denmark & 0528 & 11 Netherlands & 0395 \\
\hline France & 0605 & 12 Sweden & 0666 & 12 Sweden & 0501 & 12 France & 0391 \\
\hline Netherlands & 0594 & 13 Germany & 0619 & 13 Germany & 0430 & 13 Germany & 0390 \\
\hline Belgium & 0560 & 14 Austria & 0583 & 14 Austria & 0402 & 14 Belgium & 0350 \\
\hline Ireland & 0521 & 15 Norway & 0499 & 15 Ireland & 0370 & 15 Ireland & 0315 \\
\hline Austria & 0504 & 16 Italy & 0493 & 16 Finland & 0330 & 16 Austria & 0301 \\
\hline Italy & 0472 & 17 Czechoslovakia & 0476 & 17 Czechoslovakia & 0327 & 17 Spain & 0271 \\
\hline Finland & 0467 & 18 Spain & 0465 & 18 Italy & 0289 & 18 Italy & 0251 \\
\hline Spain & 0463 & 19 Ireland & 0448 & 19 Spain & 0254 & 19 Finland & 0230 \\
\hline Czechoslovakia & 0459 & 20 Finland & 0423 & 20 Hungary & 0237 & 20 Czechoslovakia & 0225 \\
\hline Japan & 0412 & 21 Hungary & 0388 & 21 Japan & 0221 & 21 Hungary & 0162 \\
\hline Hungary & 0378 & 22 Greece & 0383 & 22 Greece & 0218 & 22 Romania & 0156 \\
\hline Romania & 0360 & 23 Poland & 0331 & 23 Poland & 0196 & 23 Japan & 0149 \\
\hline Poland & 0349 & 24 Japan & 0282 & 24 Yugoslavia & 0191 & 24 Portugal & 0134 \\
\hline Portugal & 0329 & 25 Portugal & 0236 & 25 Romania & 0185 & 25 Poland & 0121 \\
\hline Greece & 0329 & 26 Yugoslavia & 0214 & 26 Portugal & 0179 & 26 Greece & 0100 \\
\hline Yugoslavia & 0307 & 27 Turkey & 0195 & 27 Bulgaria & 0171 & 27 Yugoslavia & 0092 \\
\hline Turkey & 0296 & 28 Bulgaria & 0185 & & & 28 Bulgaria & 0089 \\
\hline Bulgaria & 0284 & 29 Romania & 0181 & & & 29 Turkey & 0084 \\
\hline
\end{tabular}

Relative GDP per head in 1938 (interwar borders)

\begin{tabular}{|c|c|c|c|c|c|c|c|}
\hline \multicolumn{2}{|c|}{ Prados de la Escosura } & \multicolumn{2}{|c|}{ Maddison (R) } & \multicolumn{2}{|c|}{ Bairoch } & \multicolumn{2}{|c|}{ Exchange Rate } \\
\hline USA & 1000 & 1 New Zealand & 1125 & 1 USA & 1000 & 1 USA & 1000 \\
\hline Australia & 0924 & 2 Switzerland & 1074 & 2 Norway & 0837 & $2 \mathrm{UK}$ & 0877 \\
\hline Canada & 0914 & 3 USA & 1000 & 3 Switzerland & 0776 & 3 Australia & 0815 \\
\hline UK & 0898 & 4 Denmark & 0984 & 4 UK & 0761 & 4 Germany & 0808 \\
\hline New Zealand & 0843 & 5 Australia & 0967 & 5 Germany & 0726 & 5 New Zealand & 0805 \\
\hline Germany & 0811 & $6 \mathrm{UK}$ & 0959 & 6 Sweden & 0707 & 6 Canada & 0757 \\
\hline Sweden & 0810 & 7 Netherlands & 0898 & 7 Denmark & 0674 & 7 Switzerland & 0747 \\
\hline Norway & 0798 & 8 Sweden & 0892 & 8 Belgium & 0654 & 8 Norway & 0745 \\
\hline Switzerland & 0761 & 9 Germany & 0891 & 9 France & 0604 & 9 Sweden & 0703 \\
\hline
\end{tabular}


TABLE 9-Continued

\begin{tabular}{|c|c|c|c|c|c|c|c|}
\hline 10 Denmark & 0741 & 10 Argentina & 0852 & 10 Netherlands & 0593 & 10 Denmark & 0664 \\
\hline 11 Netherlands & 0704 & 11 Belgium & 0803 & 11 Finland & 0589 & 11 Netherlands & 0527 \\
\hline 12 Belgium & 0698 & 12 Canada & 0765 & 12 Ireland & 0418 & 12 Belgium & 0507 \\
\hline 13 France & 0623 & 13 France & 0749 & 13 Austria & 0413 & 13 France & 0436 \\
\hline 14 Argentina & 0588 & 14 Norway & 0671 & 14 Greece & 0380 & 14 Austria & 0420 \\
\hline 15 Finland & 0572 & 15 Austria & 0604 & 15 Italy & 0355 & 15 Italy & 0367 \\
\hline 16 Austria & 0570 & 16 Finland & 0600 & 16 Czechoslovakia & 0353 & 16 Finland & 0339 \\
\hline 17 Italy & 0529 & 17 Italy & 0569 & 17 Hungary & 0291 & 17 Argentina & 0296 \\
\hline 18 Czechoslovakia & 0509 & 18 Ireland & 0520 & 18 Bulgaria & 0271 & 18 Czechoslovakia & 0276 \\
\hline 19 Ireland & 0479 & 19 Czechoslovakia & 0486 & 19 Poland & 0240 & 19 Ireland & 0220 \\
\hline 20 Japan & 0440 & 20 Greece & 0478 & 20 Portugal & 0226 & 20 Romania & 0195 \\
\hline 21 Romania & 0418 & 21 Hungary & 0447 & 21 Romania & 0221 & 21 Hungary & 0174 \\
\hline 22 Hungary & 0395 & 22 Japan & 0405 & 22 Yugoslavia & 0219 & 22 Portugal & 0166 \\
\hline 23 Poland & 0393 & 23 Poland & 0368 & 23 Spain & 0217 & 23 Poland & 0163 \\
\hline 24 Portugal & 0379 & 24 Spain & 0330 & & & 24 Bulgaria & 0159 \\
\hline 25 Bulgaria & 0373 & 25 Portugal & 0278 & & & 25 Japan & 0136 \\
\hline 26 Turkey & 0371 & 26 Bulgaria & 0269 & & & 26 Turkey & 0126 \\
\hline 27 Greece & 0370 & 27 Turkey & 0254 & & & 27 Greece & 0117 \\
\hline 28 Yugoslavia & 0341 & 28 Yugoslavia & 0229 & & & 28 Spain & 0111 \\
\hline 29 Spain & 0331 & 29 Romania & 0209 & & & 29 Yugoslavia 0346 & \\
\hline
\end{tabular}

Relative GDP per head in 1950 (post-World War II borders)

\begin{tabular}{|c|c|c|c|c|c|c|c|}
\hline \multicolumn{2}{|c|}{ Prados de la Escosura } & \multicolumn{2}{|c|}{ Maddison (R) } & \multicolumn{2}{|c|}{ Bairoch } & \multicolumn{2}{|c|}{ Exchange Rate } \\
\hline 1 USA & 1000 & 1 USA & 1000 & 1 USA & 1000 & 1 USA & 1000 \\
\hline 2 Canada & 0882 & 2 Switzerland & 0973 & 2 New Zealand & 0885 & 2 Canada & 0664 \\
\hline 3 New Zealand & 0704 & 3 New Zealand & 0940 & 3 Canada & 0811 & 3 New Zealand & 0534 \\
\hline 4 Switzerland & 0665 & 4 Sweden & 0792 & 4 Sweden & 0764 & 4 Switzerland & 0521 \\
\hline 5 Australia & 0657 & 5 Canada & 0790 & 5 Norway & 0737 & 5 Sweden & 0463 \\
\hline 6 Sweden & 0641 & 6 Australia & 0786 & 6 Australia & 0713 & 6 Argentina & 0430 \\
\hline 7 Norway $^{a}$ & 0639 & 7 Denmark & 0758 & 7 Switzerland & 0610 & 7 Belgium & 0408 \\
\hline $8 \mathrm{UK}^{a}$ & 0616 & $8 \mathrm{UK}$ & 0718 & $8 \mathrm{UK}$ & 0603 & 8 Denmark & 0382 \\
\hline 9 Denmark $^{a}$ & 0610 & 9 Netherlands & 0655 & 9 Denmark & 0570 & 9 UK & 0378 \\
\hline 0 Argentina & 0608 & 10 Argentina & 0616 & 10 Belgium & 0521 & 10 Norway & 0367 \\
\hline France $^{a}$ & 0571 & 11 Belgium & 0602 & 11 France & 0507 & 11 Australia & 0365 \\
\hline Belgium $^{a}$ & 0552 & 12 France & 0567 & 12 Finland & 0458 & 12 France & 0364 \\
\hline Finland & 0516 & 13 Norway & 0540 & 13 Netherlands & 0455 & 13 Finland & 0307 \\
\hline Netherlands ${ }^{a}$ & 0512 & 14 Germany & 0476 & 14 Germany & 0415 & 14 Netherlands & 0264 \\
\hline Ireland & 0438 & 15 Finland & 0455 & 15 Ireland & 0332 & 15 Germany & 0257 \\
\hline Germany $^{a}$ & 0425 & 16 Austria & 0401 & 16 Austria & 0322 & 16 Austria & 0196 \\
\hline 7 Austria & 0418 & 17 Italy & 0384 & 17 Italy & 0263 & 17 Ireland & 0196 \\
\hline 8 Italy $^{a}$ & 0352 & 18 Ireland & 0375 & 18 Greece & 0199 & 18 Italy & 0186 \\
\hline 9 Spain & 0333 & 19 Spain & 0252 & 19 Japan & 0182 & 19 Spain & 0120 \\
\hline Portugal & 0325 & 20 Greece & 0218 & 20 Portugal & 0171 & 20 Greece & 0119 \\
\hline Turkey & 0315 & 21 Portugal & 0211 & 21 Spain & 0164 & 21 Portugal & 0108 \\
\hline Greece & 0301 & 22 Japan & 0205 & & & 22 Turkey & 0094 \\
\hline Japan & 0289 & 23 Turkey & 0148 & & & 23 Japan & 0069 \\
\hline
\end{tabular}

Relative GDP per head in 1960 (post-World War II borders)

\begin{tabular}{|c|c|c|c|c|c|c|c|}
\hline \multicolumn{2}{|c|}{ Prados de la Escosura } & \multicolumn{2}{|c|}{ Maddison (R) } & \multicolumn{2}{|c|}{ Bairoch } & \multicolumn{2}{|c|}{ Exchange Rate } \\
\hline 1 USA & 1000 & 1 Switzerland & 1144 & 1 USA & 1000 & 1 USA & 1000 \\
\hline 2 Canada & 0921 & 2 USA & 1000 & 2 Canada & 0865 & 2 Canada & 0786 \\
\hline 3 Sweden & 0785 & 3 New Zealand & 0898 & 3 Sweden & 0800 & 3 Sweden & 0653 \\
\hline 4 Australia & 0777 & 4 Sweden & 0850 & 4 Norway & 0734 & 4 Australia & 0578 \\
\hline 5 New Zealand & 0702 & 5 Denmark & 0822 & 5 New Zealand & 0688 & 5 Switzerland & 0555 \\
\hline 6 Switzerland & 0690 & 6 Canada & 0812 & 6 Australia & 0678 & 6 New Zealand & 0553 \\
\hline $7 \mathrm{UK}$ & 0664 & 7 Germany & 0805 & 7 Switzerland & 0651 & $7 \mathrm{UK}$ & 0480 \\
\hline 8 Germany & 0648 & 8 Australia & 0795 & 8 Germany & 0629 & 8 France & 0464 \\
\hline 9 France & 0638 & 9 Netherlands & 0775 & 9 UK & 0596 & 9 Germany & 0456 \\
\hline 10 Norway & 0631 & $10 \mathrm{UK}$ & 0773 & 10 France & 0590 & 10 Denmark & 0453 \\
\hline 11 Belgium & 0615 & 11 France & 0694 & 11 Denmark & 0583 & 11 Norway & 0450 \\
\hline 12 Denmark & 0605 & 12 Belgium & 0653 & 12 Finland & 0531 & 12 Belgium & 0424 \\
\hline Netherlands & 0590 & 13 Argentina & 0621 & 13 Belgium & 0524 & 13 Finland & 0397 \\
\hline 4 Finland & 0588 & 14 Norway & 0608 & 14 Netherlands & 0501 & 14 Netherlands & 0363 \\
\hline Austria & 0517 & 15 Austria & 0604 & 15 Austria & 0435 & 15 Austria & 0310 \\
\hline 6 Italy & 0505 & 16 Finland & 0570 & 16 Italy & 0346 & 16 Italy & 0274 \\
\hline 17 Ireland & 0461 & 17 Italy & 0555 & 17 Ireland & 0325 & 17 Ireland & 0232 \\
\hline
\end{tabular}


TABLE 9-Continued

\begin{tabular}{llllllll}
\hline 18 Argentina & 0461 & 18 Ireland & 0397 & 18 Japan & 0302 & 18 Argentina & 0205 \\
19 Japan & 0418 & 19 Japan & 0364 & 19 Greece & 0254 & 19 Japan & 0165 \\
20 Greece & 0367 & 20 Spain & 0318 & 20 Spain & 0187 & 20 Greece \\
21 Spain & 0343 & 21 Greece & 0307 & 21 Portugal & 0182 & 21 Spain \\
22 Portugal & 0339 & 22 Portugal & 0267 & & 0147 \\
23 Turkey & 0277 & 23 Turkey & 0175 & & 22 Portugal & 0119 \\
& & & 0 & & & 23 Turkey
\end{tabular}

Relative GDP per head in 1970 (post-World War II borders)

\begin{tabular}{|c|c|c|c|c|c|c|c|}
\hline \multicolumn{2}{|c|}{ Prados de la Escosura } & \multicolumn{2}{|c|}{ Maddison (R) } & \multicolumn{2}{|c|}{ Bairoch } & \multicolumn{2}{|c|}{ Exchange Rate } \\
\hline 1 USA & 1000 & 1 Switzerland & 1169 & 1 USA & 1000 & 1 USA & 1000 \\
\hline 2 Canada & 0938 & 2 USA & 1000 & 2 Sweden & 0886 & 2 Sweden & 0837 \\
\hline 3 Sweden & 0854 & 3 Sweden & 0940 & 3 Norway & 0858 & 3 Canada & 0802 \\
\hline 4 Australia & 0789 & 4 Denmark & 0892 & 4 Canada & 0840 & 4 Switzerland & 0665 \\
\hline 5 Netherlands $^{b}$ & 0780 & 5 Germany & 0856 & 5 France & 0726 & 5 Denmark & 0643 \\
\hline 6 Germany $^{b}$ & 0771 & 6 Canada & 0844 & 6 Germany & 0721 & 6 Australia & 0632 \\
\hline 7 France $^{b}$ & 0760 & 7 Netherlands & 0843 & 7 Australia & 0715 & 7 Germany & 0611 \\
\hline 8 Switzerland & 0742 & 8 Australia & 0817 & 8 Denmark & 0679 & 8 Norway & 0579 \\
\hline 9 Norway & 0736 & 9 France & 0811 & 9 Switzerland & 0677 & 9 France & 0565 \\
\hline 10 Belgium $^{b}$ & 0734 & 10 New Zealand & 0804 & 10 Finland & 0666 & 10 Netherlands & 0528 \\
\hline 11 Denmark & 0717 & $11 \mathrm{UK}$ & 0766 & 11 New Zealand & 0657 & 11 Belgium & 0525 \\
\hline $12 \mathrm{UK}^{b}$ & 0671 & 12 Belgium & 0756 & 12 Belgium & 0630 & 12 Finland & 0476 \\
\hline 13 Finland & 0627 & 13 Italy & 0686 & 13 Japan & 0584 & 13 New Zealand & 0467 \\
\hline 14 Italy $^{b}$ & 0616 & 14 Austria & 0681 & 14 Netherlands & 0584 & $14 \mathrm{UK}$ & 0448 \\
\hline $15 \operatorname{Japan}^{b}$ & 0611 & 15 Japan & 0668 & $15 \mathrm{UK}$ & 0571 & 15 Italy & 0401 \\
\hline 16 New Zealand & 0593 & 16 Finland & 0663 & 16 Austria & 0509 & 16 Japan & 0392 \\
\hline 17 Austria & 0561 & 17 Norway & 0638 & 17 Italy & 0427 & 17 Austria & 0389 \\
\hline 18 Ireland & 0489 & 18 Argentina & 0614 & 18 Greece & 0395 & 18 Ireland & 0270 \\
\hline 19 Argentina & 0455 & 19 Spain & 0468 & 19 Ireland & 0366 & 19 Argentina & 0240 \\
\hline
\end{tabular}

Relative GDP per head in 1975 (post-World War II borders)

\section{Prados de la Escosura}

1 USA

2 Canada

3 Sweden

4 France $^{c}$

5 Australia

6 Norway

7 Germany $^{c}$

8 Switzerland

9 Denmark $^{c}$

10 Netherlands ${ }^{c}$

11 Belgium $^{c}$

12 Finland

13 Austria $^{c}$

14 Japan $^{c}$

$15 \mathrm{UK}^{c}$

16 New Zealand

17 Italy $^{c}$

18 Spain $^{c}$

19 Greece

20 Ireland $^{c}$

21 Argentina

22 Portugal

23 Turkey
Maddison (R)

\begin{tabular}{lll}
\multicolumn{3}{c}{ Maddison (R) } \\
1 Switzerland & 1094 \\
2 USA & 1000 \\
3 Sweden & 0998 \\
4 Canada & 0945 \\
5 Denmark & 0885 \\
6 Belgium & 0882 \\
7 France & 0878 \\
8 Netherlands & 0871 \\
9 Germany & 0865 \\
10 New Zealand & 0836 \\
11 Australia & 0823 \\
12 UK & 0774 \\
13 Austria & 0752 \\
14 Finland & 0731 \\
15 Norway & 0717 \\
16 Japan & 0717 \\
17 Italy & 0705 \\
18 Argentina & 0633 \\
19 Spain & 0567 \\
20 Greece & 0525 \\
21 Ireland & 0453 \\
22 & Portugal & 0395 \\
23 & Turkey & 0209
\end{tabular}

Bairoch

1 USA
2 Norway
3 Sweden
4 France
5 Germany
6 Finland
7 Denmark
8 Switzerland
9 Belgium
10 Netherlands
11 UK
12 Austria
13 Greece
14 Italy
15 Ireland
16 Portugal
17 Spain

Exchange Rate

$1000 \quad 1$ Sweden 1210

$0861 \quad 2$ Switzerland $\quad 1153$

$0840 \quad 3$ Denmark 1012

$0746 \quad 4$ Canada 1011

$0708 \quad 5$ USA 1000

$0689 \quad 6$ Australia $\quad 0982$

$0669 \quad 7$ Norway $\quad 0966$

$0655 \quad 8$ Germany 0918

$0654 \quad 9$ Netherlands $\quad 0888$

057510 France 0884

056211 Belgium 0858

053412 Finland $\quad 0808$

$0436 \quad 13$ Austria $\quad 0676$

$0417 \quad 14$ New Zealand $\quad 0619$

036315 Japan $\quad 0608$

$0307 \quad 16$ UK 0573

$0290 \quad 17$ Italy 0521

18 Spain 0394

19 Ireland 0353

20 Greece 0315

21 Portugal 0264

22 Argentina 0261

23 Turkey $\quad 0116$

Relative GDP per head in 1980 (post-World War II borders)

Prados de la Escosura

$\begin{array}{ll}1 \text { USA } & 1000 \\ 2 \text { Norway }^{d} & 0994 \\ 3 \text { Canada }^{d} & 0976 \\ 4 \text { Sweden }^{2} \text { Switzerland }_{6} & 0938 \\ 6 \text { France }^{d} & 0912 \\ 7 \text { Germany }^{d} & 0866 \\ 8 \text { Denmark }^{d} & 0859 \\ & 0852\end{array}$

Maddison (R)

$\begin{array}{ll}1 \text { Switzerland } & 1056 \\ 2 \text { USA } & 1000 \\ 3 \text { Canada } & 0951 \\ 4 \text { Germany } & 0896 \\ 5 \text { France } & 0889 \\ 6 \text { Sweden } & 0888 \\ 7 \text { Denmark } & 0870 \\ 8 \text { Netherlands } & 0841\end{array}$

Exchange Rate

$\begin{array}{lll}1 \text { Switzerland } & 1345 \\ 2 & \text { Sweden } & 1257 \\ 3 \text { Norway } & 1181 \\ 4 \text { Germany } & 1101 \\ 5 \text { Denmark } & 1083 \\ 6 \text { France } & 1032 \\ 7 \text { Netherlands } & 1026 \\ 8 \text { Belgium } & 1003\end{array}$


TABLE 9-Continued

\begin{tabular}{|c|c|c|c|c|c|}
\hline 11 Belgium $^{d}$ & 0831 & 11 Norway & 0783 & 11 Australia & 0909 \\
\hline 13 Italy $^{d}$ & 0803 & 13 Italy & 0768 & 13 Austria & 0852 \\
\hline 14 Japan $^{d}$ & 0785 & 14 Japan & 0753 & $14 \mathrm{UK}$ & 0803 \\
\hline 17 New Zealand & 0655 & 17 New Zealand & 0725 & 17 Argentina & 0622 \\
\hline 18 Spain $^{d}$ & 0577 & 18 Argentina & 0564 & 18 New Zealand & 0601 \\
\hline 19 Argentina $^{d}$ & 0552 & 19 Spain & 0548 & 19 Ireland & 0473 \\
\hline 20 Ireland $^{d}$ & 0533 & 20 Greece & 0536 & 20 Spain & 0473 \\
\hline 21 Portugal $^{d}$ & 0468 & 21 Ireland & 0462 & 21 Greece & 0348 \\
\hline
\end{tabular}

Relative GDP per head in 1985 (post-World War II borders)

\begin{tabular}{|c|c|c|}
\hline \multicolumn{3}{|c|}{ Prados de la Escosura } \\
\hline 1 & USA & 1000 \\
\hline 2 & Canada $^{e}$ & 0925 \\
\hline 3 & Norway $^{e}$ & 0869 \\
\hline 4 & Sweden ${ }^{e}$ & 0816 \\
\hline 5 & Japan ${ }^{e}$ & 0783 \\
\hline 6 & Australia $^{e}$ & 0783 \\
\hline 7 & Denmark $^{e}$ & 0782 \\
\hline 8 & Switzerland & 0773 \\
\hline 9 & France $^{e}$ & 0752 \\
\hline 10 & Germany $^{e}$ & 0751 \\
\hline 11 & Netherlands ${ }^{e}$ & 0722 \\
\hline 12 & Finland $e$ & 0708 \\
\hline 13 & Italy $^{e}$ & 0706 \\
\hline 14 & $\mathrm{UK}^{e}$ & 0703 \\
\hline 15 & Belgium $^{e}$ & 0686 \\
\hline 16 & Austria $^{e}$ & 0678 \\
\hline 17 & New Zealand ${ }^{e}$ & 0642 \\
\hline 18 & Spain $^{e}$ & 0499 \\
\hline 19 & Ireland ${ }^{e}$ & 0421 \\
\hline 20 & Greece $^{e}$ & 0419 \\
\hline 21 & Portugal $^{e}$ & 0414 \\
\hline & Argentina & 0382 \\
\hline 23 & Turkey $^{e}$ & 0302 \\
\hline
\end{tabular}

\begin{tabular}{ll}
\multicolumn{2}{c}{ Maddison (R) } \\
1 Switzerland & 1008 \\
2 USA & 1000 \\
3 Canada & 0931 \\
4 Denmark & 0905 \\
5 Sweden & 0878 \\
6 Germany & 0872 \\
7 France & 0846 \\
8 Norway & 0828 \\
9 Japan & 0798 \\
10 Netherlands & 0786 \\
11 Belgium & 0783 \\
12 Australia & 0780 \\
13 Austria & 0760 \\
14 UK & 0743 \\
15 Finland & 0743 \\
16 Italy & 0741 \\
17 New Zealand & 0737 \\
18 Spain & 0520 \\
19 Greece & 0506 \\
20 Ireland & 0447 \\
22 Prgentina & 0431 \\
23 Turkey & 0424 \\
\end{tabular}

\begin{tabular}{ll}
\multicolumn{2}{c}{ Exchange Rate } \\
1 USA & 1000 \\
2 Switzerland & 0854 \\
3 Norway & 0835 \\
4 Canada & 0819 \\
5 Sweden & 0718 \\
6 Denmark & 0676 \\
7 Japan & 0661 \\
8 Finland & 0649 \\
9 Australia & 0633 \\
10 Germany & 0605 \\
11 France & 0565 \\
12 Netherlands & 0531 \\
13 Austria & 0514 \\
14 Belgium & 0482 \\
15 UK & 0481 \\
16 Italy & 0443 \\
17 New Zealand & 0399 \\
18 Ireland & 0315 \\
19 Spain & 0254 \\
20 Greece & 0201 \\
23 Prgentina & 0182 \\
& 0142 \\
23 & 0080
\end{tabular}

Relative GDP per head in 1990 (post-World War II borders)

\begin{tabular}{|c|c|c|}
\hline \multicolumn{3}{|c|}{ Prados de la Escosura } \\
\hline 1 & Switzerland $f$ & 1025 \\
\hline 2 & USA & 1000 \\
\hline 3 & Canada ${ }^{f}$ & 0939 \\
\hline 4 & Germany $^{f}$ & 0916 \\
\hline 5 & Japan $^{f}$ & 0900 \\
\hline 6 & Denmark $^{f}$ & 0893 \\
\hline 7 & France $f$ & 0890 \\
\hline 8 & Sweden $f$ & 0878 \\
\hline 9 & Belgium $f^{f}$ & 0843 \\
\hline 10 & Netherlands $f$ & 0819 \\
\hline 11 & Norway ${ }^{f}$ & 0809 \\
\hline 12 & Italy $f$ & 0808 \\
\hline 13 & Austria $f$ & 0795 \\
\hline 14 & Finland $f$ & 0794 \\
\hline 15 & $\mathrm{UK}^{f}$ & 0793 \\
\hline 16 & Australia $^{f}$ & 0787 \\
\hline 17 & New Zealand $f$ & 0659 \\
\hline 18 & Spain $f$ & 0578 \\
\hline 19 & Portugal $^{f}$ & 0528 \\
\hline 20 & Ireland $f$ & 0502 \\
\hline 21 & Greece $^{f}$ & 0395 \\
\hline
\end{tabular}

\begin{tabular}{ll}
\multicolumn{2}{c}{ Maddison (R) } \\
1 Switzerland & 1032 \\
2 USA & 1000 \\
3 Canada & 0932 \\
4 Germany & 0910 \\
5 Denmark & 0891 \\
6 Japan & 0890 \\
7 France & 0881 \\
8 Sweden & 0874 \\
9 Belgium & 0829 \\
10 Netherlands & 0813 \\
11 Norway & 0803 \\
12 Austria & 0791 \\
13 Finland & 0791 \\
14 UK & 0787 \\
15 Australia & 0783 \\
16 Italy & 0782 \\
17 New Zealand & 0678 \\
18 Spain & 0584 \\
19 Portugal & 0526 \\
20 Ireland & 0520 \\
21 Greece & 0492
\end{tabular}

\begin{tabular}{ll}
\multicolumn{2}{c}{ Exchange Rate } \\
1 Switzerland & 1530 \\
2 Finland & 1241 \\
3 Sweden & 1233 \\
4 Denmark & 1157 \\
5 Norway & 1146 \\
6 Japan & 1097 \\
7 Germany & 1093 \\
8 USA & 1000 \\
9 Canada & 0986 \\
10 France & 0972 \\
11 Austria & 0943 \\
12 Belgium & 0898 \\
13 Netherlands & 0874 \\
14 Italy & 0871 \\
15 Australia & 0797 \\
16 UK & 0783 \\
17 New Zealand & 0578 \\
18 Spain & 0571 \\
19 Ireland & 0560 \\
20 Portugal & 0316 \\
21 Greece & 0302
\end{tabular}


TABLE 9-Continued

\begin{tabular}{lllllr}
\hline 22 & Argentina & 0385 & 22 Argentina & 0376 & 22 Argentina \\
23 Turkey $^{f}$ & 0297 & 23 Turkey & 0213 & 23 Turkey \\
\hline
\end{tabular}

a Computed with Gilbert and Kravis's Paasche PPPs

${ }^{b}$ Computed with ICP II Paasche PPPs

c Computed with ICP III Paasche PPPs

${ }^{d}$ Computed with ICP IV Paasche PPPs

$e$ Computed with ICP V Paasche PPPs

$f$ Computed with ICP VI Paasche PPPs

Sources. Trading exchange rates, national sources up to 1913, such as Carreras (1989), Lains (1995), Lazaretou (1995), Mata and Valerio (1994), Simon (1960), and, especially, cross-country quotations from Antio (1992), Posthumus (1946), Schneider and Schwarzer (1990), and Schneider et al. (1993) For 1913-1938, League of Nations' Yearbooks and U S Statistical Abstract; IMF Yearbooks for 1950-1990 The Maddison (R) column, refers to GDP per head expressed in 1990 U S dollars (at U S relative prices), computed from Maddison (1995) but revised with the latest GDP data available for each country as explained in the sources below in order to make it consistent with the new estimates Maddison's 1990 "international dollars" (Geary-Khamis) were previously converted into U S dollars with Maddison (1995, Table C-6) own appropriate ratios The Bairoch column derives from Bairoch (1976, 1981, 1989), and refers to GDP per head in 1960 U S dollars New current price estimates of GDP per head (column under Prados de la Escosura) are computed by converting product per head expressed in national currencies into U S dollars with Paasche PPPs derived from Eq (II) in Table 4 and represent real income expressed in U S relative prices (Laspeyres values) Nominal GDP estimates are (whenever possible) define at market prices per head and come from the following national sources stated below or from Mitchell (1992, 1993, 1994)) or from OECD National Accounts and UN Yearbooks Population and trade figure are taken mainly from Mitchell (1992, 1993, 1994), and from the League of Nations, UN, and UNCTAD Yearbooks, unless stated in the national sources below Area surface comes from the World Almanac (1988), Cook and Paxton (1975), and, for Greece, Kostis and Petmezas (1998) National sources:

Argentina GDP, Taylor (1998) for 1885-1990 (Cortes Conde (1997) for 1875-1935 at constant prices)

Austria GDP, data for Imperial (Habsburg) Austria are from Kausel (1979) for 1830-1860, and for 1870-1913 are from Schulze (1997), at 1913 prices, reflate with Kausel's implicit GDP deflato Modern (Republic of) Austria's level for 1913 was derived by applying Good's (1994) ratio (1 346) to Schulze's Imperial estimates Trade, crude computations from data on the share of Imperial Austria in Austria-Hungary trade derived from Eddie (1980) for 1880-1913 and extended back to 1830 Eddie (1980) provides Imperial Austria's share in Austria-Hungary trade and, therefore, trade by Imperial Austria can be derived, which includes reexports to and from Hungary Eddie presents shares of Austria in Hungary's trade, so Austrian trade with the rest of the world can easily be computed A difficulty appears as regards the share of Austrian trade with Hungary that represents domestic exports and retained or net imports and not just reexports Given the lack of information, I decided to consider reexports negligible and to attribute all the trade between Imperial Austria and Hungary to domestic exports and retained imports The computed share of Austria in Austria-Hungary trade for 1880 was applied to trade figure for the Dual Monarchy in earlier years in order to derive Austrian exports and imports back to 1830

Belgium GDP, Horlings (1997), 1830-1913; average of GDP estimates from Buyst (1997) (income and expenditure approaches) and Horlings (1997) (output), for 1925-1938

Canada GDP and Trade Firestone (1960), 1850-1860 Urquhart (1986), 1870-1926 Although Urquhart seems to favour GNP, GDP was preferred to GNP here

Czechoslovakia GDP, Clark (1957), NNP for 1913 and 1925, rescaled by 5\% to allow for the GNP/NNP differential Krejci (1968), 1929-1937 at current prices Given the missing figure the level of GDP per head for 1938 has been considered identical to that for 1937 (Pryor et al. (1971) provide an index of real GDP for 1913-1937)

Denmark GDP, Hansen (1974), 1820-1955

Finland GDP, Hjerppe (1994), 1860-1950 (at constant prices, 1860-1990)

France GDP, Toutain (1997), 1830-1938 (at constant prices, 1820-1990) Toutain's recently revised figure are significantl higher than those in Levy-Leboyer and Bourguignon (1985)

Germany Germany, 1850-1938; West Germany, 1950-1990 GDP, 1850-1900, Hoffmann (1965); 1901-1990, Ritschl and Spoerer (1997) For 1850-1900, GNP at market prices was obtained by rescaling NNP at market prices with the GNP/NNP ratio for 1901, from Ritschl and Spoerer (1997) For 1850-1913, GDP at market prices was computed from the GNP estimates and from data on net factor payments abroad in Hoffmann (1965) West German figure do not include the Saar and West Berlin for 1950-1955 (The constant price data have been extended back to 1830 with Fremdling (1995) estimates) Trade, Bondi (1958), 1850-1870; Hoffmann (1965), $1880-1955$

Greece GDP, Kostelenos (1995), 1860-1938

Hungary GDP, data for 1870-1913 at 1913 prices from Schulze (1998) reflate with Kausel's (1979) implicit GDP deflato (for Imperial Austria) to derive current price estimates for Imperial (Habsburg) Hungary In turn, figure for Modern (Republic of) Hungary 
in the period 1913-1938 were taken from Eckstein (1955) for the country as define by the treaty of Trianon (1919) Modern (Republic of) Hungary's level for 1913 could alternatively be derived by applying Good's (1994) ratio (1 24) to Schulze's (1997) Imperial estimates However, the difference between the new estimate by Schulze and Eckstein's for modern Hungary in 1913 is striking Eckstein's figure for Trianon Hungary were 87 6\% of Schulze's Imperial Hungary, but since Schulze's Imperial Hungary includes two poorer regions (modern Romania and Yugoslavia), even though Eckstein's figure refer to NNP, Eckstein's estimates should be higher Eckstein's estimates represent only $707 \%$ of modern Hungary per capita income derived by applying Good's (1994) ratio to the Imperial Hungary figures I therefore decided to choose Eckstein's data and to reflat it by 5\% to allow for GNP-NNP differences (a percentage taken from the same ratio for Germany in 1950) Trade, crude computations from data on the share of Imperial Hungary in Austria-Hungary trade derived from Eddie (1980) for 1880-1913 and extended to 1870 Eddie (1980) provides Imperial Austria's share in Austria-Hungary trade and, therefore, trade by Imperial Hungary can be derived, which includes reexports to and from Austria Eddie presents shares of Hungary in Austrian trade, so Hungarian trade with the rest of the world can easily be computed A difficulty appears as regards the share of Hungarian trade with Austria that represents domestic exports and retained or net imports and not just reexports Given the lack of information, I decided to consider reexports negligible and to attribute all the trade between Imperial Austria and Hungary to domestic exports and retained imports The computed share of Hungary in Austria-Hungary trade for 1880 was applied to trade figure of the Dual Monarchy in order to derive exports and imports from Hungary in 1870

Ireland GDP, all Ireland, estimate for 1913 by O Grada (1994) For the Republic of Ireland, the 1913 value was computed by applying the Republic of Ireland/Ireland ratio in Kennedy (1995, Table 2) to O Grada's (1994) estimates for all Ireland Republic of Ireland, O'Rourke's (1995) estimate for 1926 was accepted for 1925 Kennedy (1971) for 1929-1965 (both at current and constant prices) Trade, all Ireland for 1913, private communication by Kevin O'Rourke 1926-1965, Kennedy (1971) for the Republic of Ireland

Italy GDP, current price estimates, Rossi et al. (1993), 1890-1990 ISTAT figure for 1861-1890, rescaled to match the 1890 level It has been argued that Rossi et al.'s estimates might exaggerate late 19th and mid-20th century levels (Ercolani (1993)) (Maddison (1992) for GDP at constant prices, 1861-1990)

Japan GDP and Trade, Ohkawa and Shinohara (1979), 1885-1955 (at constant prices, 1885-1938) I accepted for 1880 the level of product per head for 1885 Although the authors seem to favor GNP, GDP was prefered to GNP

Netherlands GDP and Trade, Smits et al. (1999), 1820-1913; Bakker et al. (1990), 1925-1938 An average of income, output, and expenditure GDP estimates has been considered here for 1820-1913

Norway GDP at constant prices, Hodne and Grytten (1994), 1830-1913

New Zealand GDP and Trade, Rankin (1992), 1860-1938

Portugal GDP, for 1850-1900, Justino's (1987) indirect estimates provide a better alternative than Nunes et al. (1989) and Valerio (1998), whose figure seem implausibly high (twice as much as Justino's and 18 times those of Batista et al. (1997) for 1913) For 1910-1950 I prefered Batista et al.'s (1997) estimates of GDP at current prices, rescaled to match Pinheiro's (1997) GDP level for 1953, to indirect estimates by Nunes et al. (1989) and Valerio (1998) For 1955-1990, Pinheiro (1997) Trade, Lains (1995), for 1850-1913; Valaerio (1998), 1920-1938; Pinheiro (1997), 1955-1990

Romania GDP, 1925-1938, Lethbridge (1985)

Russia GDP, Imperial Russia, Gregory (1982), 1885-1913 As in the case of Japan, I accepted for 1880 the level of product per head for 1885 Original NNP figure were firs converted into NDP by deducting net payments to foreign factors and then rescaled by $5 \%$ to allow for the GDP/NDP differential

Spain GDP and Trade, Prados de la Escosura (2000), 1850-1990

Sweden GDP, Krantz (1997), 1820-1950 (at constant prices, 1820-1990)

Switzerland GDP, Ritzmann-Blickenstorfer (1996), 1880-1890, linked to Ritzmann-Blickenstorfer (1999), 1890-1950

Turkey GDP and Trade, 1913-1938, private communications by Sevket Pamuk which derive from Ozel (1997), and Pamuk (1998)

United Kingdom GDP, Mitchell (1988) publishes revised estimates by Feinstein that updates his earlier work (Feinstein (1972)) and links them to Deane's (1968) figure for 1830-1850 in order to provide consistent figure for GDP at market prices The figur for 1850 was derived by applying the 1850/1851 ratio in Mitchell's (1988) series to Feinstein's (1998) new direct GDP estimates for 1851 A GDP estimate for 1820 was derived by applying the ratio of Mitchell's (1988) to Deane and Cole's (1967) estimates for 1831 to Deane and Cole's 1821 figur at current prices Corresponding values for the post-1921 United Kingdom in the year 1913 were computed by subtracting estimates for the Republic of Ireland (see above) from Feinstein's figure for the pre-1921 United Kingdom (Great Britain and Ireland) Trade, Mitchell (1988)

United States GDP, Balke and Gordon (1989), 1870-1929 For 1820-1860, David (1996), "narrow" estimates at constant prices, which coincide with Weiss's (1994) "conventional estimate" for 1840-1860 These estimates have been reflate with a weighted average of the David-Solar (1977) cost of living index (5/6) and the Berry (1968) implicit GDP deflato, actually a wholesale price index (1/6) Weights roughly proximate the shares of investment and consumption in GDP during 1820-1860 (I owe the suggestion to Paul David) GDP was computed by deducting net payments to foreign factors from GNP figures Trade, North (1960), 1820-1860; Simon (1960), 1870-1900 
considerable degree in price levels. PLs are a rising function of the stage of development (Summers and Heston (1991)), and market exchange rates tend to exaggerate the national price levels for low income countries. In fact, the new PLs show that this was generally the case, although higher price levels in the Americas and Oceania are probably related to labor, while trade barriers help to explain relatively high price levels in some Peripheral countries. ${ }^{55}$

Furthermore, a closer look at implicit PLs in Maddison's estimates is instructive. ${ }^{56}$ For example, over the years $1870-1913$, the U.K. price level remains, on average, at $76 \%$ of the U.S. price level. Maddison's observation is clearly at odds with the new evidence (just $4 \%$ below the U.S. on average), that shows an over-time decline in the British price level from 3\% above to $15 \%$ below the U.S. level. The persistent and significantl lower price level in the U.K., as presented in Maddison's estimates, does not seem to be a plausible outcome during a period of commodity and factor price convergence and the rise of American leadership (Williamson (1996)). Moreover, it is also quite unlikely that the commercial exchange rate and the PPP for the two most advanced, open economies, the United Kingdom and the United States, were so far apart under the classical gold standard. ${ }^{57}$ It can be argued, against this view, that the United Kingdom was a free trader whereas the United States was a protectionist country, which would explain the high price differential between the two countries over the 19th century. A wider view taking into account not only institutional barriers to commodity trade but the impressive decline in transport costs and the lack of restrictions to intercontinental flow of labor and capital that led to commodity and factor price convergence would depict the United States as a country much more integrated into the global Atlantic economy (O'Rourke and Williamson (1997); O'Rourke et al. (1996)).

Some of the main differences between new and older data sets could be attributed to the fact that these comparisons are between estimates expressed in current and constant prices, respectively. Different representations certainly occur from comparisons in constant prices. ${ }^{58}$ Computations of GDP levels at constant price with a fixe PPP-converted benchmark on the basis of the best available data are needed to show the extent to which differences in older and more recent

55 Levels of average nominal protection for the decades before World War I (Bairoch (1989)) help to understand why poor but protectionist countries (i.e., Spain in the late $19^{\text {th }}$ century) do not improve their relative position in PPP-adjusted income estimates compared to exchange-rate-adjusted ones as much as other countries in the same range of per capita product (i.e., Sweden), since their domestic price levels are relatively high.

56 Price levels $(\mathrm{PL})$ are define as follows: $\mathrm{PL}=\mathrm{PPP} / \mathrm{ER}=(\mathrm{NGDP} / \mathrm{ER}) /(\mathrm{NGDP} / \mathrm{PPP})$, where NGDP is GDP expressed in national currency and PPP and ER are purchasing power parity and trading exchange rates, respectively.

${ }^{57}$ In the context of advanced, open countries under the classical gold standard, Crafts (1984b) claimed that comparisons on the basis of the trading exchange rates are acceptable.

58 It should be remembered that both O'Brien and Keyder (1978) and Fremdling (1991) carried out their comparison for France and Germany with Britain at current prices and the relative positions of the two countries followed somehow similar patterns to those derived from the new data set. 
estimates of GDP change the inferences drawn from current price estimates compared to data sets produced by Bairoch and Maddison. In Prados de la Escosura (2000a), the positions of countries relative to the United Kingdom are provided, for example, at constant 1913 U.S. relative prices for 1820-1913, obtained by projecting backward from the new benchmark of 1913 real per capita income with volume indices derived from historical national accounts. A comparison between current and constant price estimates shows that while, at current prices, the United States was already in front by 1880; the United States only moved ahead of the United Kingdom in 1900 when measured in 1913 dollars.

Thus, the relative positions of countries in these league tables depend upon both price and quantity. While the literature on international comparisons of income has concentrated mostly on quantity effects by utilizing a fixe PPPconverted benchmark for GDP levels and backcasting them with national indices of real product, very limited attention has been paid to changes in the price levels of countries despite the fact that inconsistencies in rankings have been frequently pointed out for the results of successive ICP rounds.

\section{FINAL REMARKS}

In this paper I have constructed a set of per capita GDP estimates at current prices, converted into common currency units and adjusted for differences in purchasing power of national currencies for more than 20 nations going back to 1820. These numbers were obtained through a short-cut method designed to derive levels of income for countries and periods for which aggregate PPPs are not yet available. My results have more intuitive economic appeal than earlier estimates expressed in present-day constant dollars. They should allow far more statistically secure comparisons of real income and productivity levels across countries. Alongside space comparisons, the new estimates render less remote benchmark comparisons over time than widely used estimates in 1960, 1970, or 1990 "international" dollars. Nonetheless, data are subject to a continuous process of refinemen and improvement as the pioneering contributions by Bairoch and Maddison show. The new data set is only another step to produce acceptable and comparable estimates of real product across countries and over time, a precondition for findin explanations for the relative economic performance of nations.

\section{REFERENCES}

Abramovitz, M., and David, P. A. (1996), “Convergence and Deferred Catch-Up: Productivity Leadership and the Waning of American Exceptionalism.” In R. Landau, T. Taylor, and G. Wright (Eds.), The Mosaic of Growth. Stanford, CA: Stanford Univ. Press. Pp. 21-62.

Ahmad, S. (1988), "International Real Income Comparisons with Reduced Information." In J. Salazar-Carrillo and D. S. Prasada Rao (Eds.), World Comparisons of Incomes, Prices, and Product. Amsterdam: North-Holland. Pp. 75-92.

Ahmad, S. (1994), "Improving Inter-spatial and Inter-temporal Comparability of National Accounts." Journal of Development Economics 44, 53-75. 
Ahmad, S. (1996), "Regression Estimates of Per Capita GDP Based on Purchasing Power Parities.” In D. S. Prasada Rao and J. Salazar-Carrillo (Eds.), International Comparisons of Prices, Output and Productivity. Amsterdam: North-Holland. Pp. 237-264.

Ahmad, S. (1998), "International Comparisons of Incomes: Why Should One Bother Using PPP Conversion?" Presented at the PREM seminar Price and Purchasing Power Parities at the World Bank.

Antio, J. (1992), Valuuttakurssit Suomessa 1864-1991. Katsaus ja tilastosarjat. Bank of Finland Discussion Paper 1/92.

Bairoch, P. (1976), "Europe's Gross National Product: 1800-1975." Journal of European Economic History 5, 273-340.

Bairoch, P. (1981), "The Main Trends in National Economic Disparities since the Industrial Revolution." In P. Bairoch and M. Lévy-Leboyer (Eds.), Disparities in Economic Development since the Industrial Revolution. London: Macmillan. Pp. 3-17.

Bairoch, P. (1989), “European Trade Policy, 1815-1914.” In P. Mathias and S. Pollard (Eds.), The Cambridge Economic History of Europe. Vol. VII. The Industrial Economies The Development of Economic and Social Policies. Cambridge, UK. Cambridge Univ. Press. Pp. 1-160.

Bakker, G. P. den, Huitker, T. A., and van Bochove, C. A. (1990), “The Dutch Economy 1921-1938: Revised Macroeconomic Data for the Interwar Period." Review of Income and Wealth 36, 187-206.

Balassa, B. (1961), "Patterns of Industrial Growth: Comment." American Economic Review 51, 394-397.

Balassa, B. (1964), “The Purchasing Power Parity Doctrine: A Reappraisal.” Journal of Political Economy 72, 584-597.

Balassa, B. (1973), "Just How Misleading Are Official Exchange Rate Conversions? A Comment." Economic Journal 83, 1258-1267.

Balassa, B. (1974), “The Rule of Four-Ninths: A Rejoinder.” Economic Journal 84, 609-614.

Balke, N. S., and Gordon, R. J. (1989), "The Estimation of Prewar Gross National Product: Methodology and New Evidence.” Journal of Political Economy 97, 38-92.

Batista, D., Martins, C., Pinheiro, M., and Reis, J. (1997), New Estimates of Portugal's GDP 1910-1958. Lisbon: Banco de Portugal.

Ben-David, D., and Loewy, M. B. (1998), "Free Trade, Growth, and Convergence." Journal of Economic Growth 3, 143-170.

Berry, T. S. (1968), Estimated Annual Variations in Gross National Product, 1789 to 1909. Richmond, VA: Bostwick Press.

Bhagwati, J. N. (1984), “Why Are Services Cheaper in the Poor Countries?” Economic Journal 94, 279-286.

Bhagwati, J. N., and Hansen, B. (1973), "Should Growth Rates Be Evaluated at International Prices?" In J. N. Bhagwati and R. S. Eckaus (Eds.), Development and Planning Essays in Honour of Paul Rosenstein-Rodan. Cambridge, MA: MIT Press. Pp. 53-68.

Bondi, G. (1958), Deutschlands Aussenhandel, 1815-1870. Berlin: Akademie Verlag.

Bordo, M. D., and Schwartz, A. J. (1996), “The Operation of the Specie Standard. Evidence for Core and Peripheral Countries, 1880-1990." In J. Braga de Macedo, B. Eichengreen, and J. Reis (Eds.), Currency Convertibility. The Gold Standard and Beyond. London: Routledge. Pp. 11-83.

Broadberry, S. N. (1994), "Comparative Productivity in British and American Manufacturing during the Nineteenth Century." Explorations in Economic History 31, 521-548.

Broadberry, S. N. (1997), "Forging Ahead, Falling Behind and Catching-Up: A Sectoral Analysis of Anglo-American Productivity Differences." Research in Economic History 17, 1-37.

Broadberry, S. N., and Fremdling, R. (1990), "Comparative Productivity in Britain and German Industry, 1907-1937." Oxford Bulletin of Economics and Statistics 52, 403-421.

Burger, A. (1997), "Dutch Industry in International Perspective 1850-1913." Presented at the Conference on Historical National Accounts for the Netherlands. Economic Growth and Structural Change 1800-1913, Utrecht: N. W. Posthumus Instituut.

Buyst, E. (1997), "New GNP Estimates for the Belgian Economy during the Interwar Period." Review of Income and Wealth 43, 357-375. 
Carreras, A. (Ed.) (1989), Estadısticas historicas de España. Madrid: Banco Exterior.

Clague, C. K. (1985), “A Model of Real National Prices.” Southern Economic Journal 51, 998-1017.

Clague, C. K. (1986a), "Determinants of the National Price Level: Some Empirical Results.” Review of Economics and Statistics 68, 320-323.

Clague, C. K. (1986b), "Short-Cut Estimates of Real Income." Review of Income and Wealth 32, 313-331.

Clague, C. K. (1988), "Explanations of National Price Levels." In J. Salazar-Carrillo and D. S. Prasada Rao (Eds.), World Comparisons of Incomes, Prices and Product. Amsterdam: Elsevier. Pp. 237-262.

Clague, C. K., and Tanzi, V. (1972), "Human Capital, Natural Resources and the Purchasing Power Doctrine: Some Empirical Results." Economia Internazionale 25, 2-18.

Clark, C. (1957), The Conditions of Economic Progress, $3^{\text {rd }}$ ed. London: Macmillan.

Cook, C., and Paxton, J. (1975), European Political Facts 1918-73. London: Macmillan.

Cortés Conde, R. (1997), La economıa argentina en el largo plazo (Siglos XIX y XX). Buenos Aires: Editorial Sudamericana-Universidad de San Andrés.

Crafts, N. F. R. (1983), "Gross National Product in Europe 1870-1910: Some New Estimates." Explorations in Economic History 20, 387-401.

Crafts, N. F. R. (1984a), "Economic Growth in France and Britain, 1830-1910: A Review of the Evidence." Journal of Economic History 44, 49-67.

Crafts, N. F. R. (1984b), "Patterns of Development in Nineteenth Century Europe." Oxford Economic Papers 15, 438-458.

Crafts, N. F. R. (1997), “The Human Development Index and Changes in Standard of Living: Some Historical Comparisons." European Review of Economic History 1, 299-322.

Dabán, T., Doménech, R., and Molinas, C. (1997), "International and Intertemporal Comparisons of Real Product in OECD Countries: A Growth Sensitivity Analysis." Review of Income and Wealth 43, 33-48.

David, P. A. (1972), “Just How Misleading Are Official Exchange Rate Conversions?” Economic Journal 82, 979-990.

David, P. A. (1973), “A Reply to Professor Balassa.” Economic Journal 83, 1267-1276.

David, P. A. (1996), Real Income and Economic Welfare Growth in the Early Republic or, Another Try at Getting the American Story Straight. University of Oxford Discussion Papers in Economic and Social History, No. 5.

David, P. A., and Solar, P. (1977), "A Bicentenary Contribution to the History of the Cost of Living in America." Research in Economic History 2, 1-80.

David, P. A., and Wright, G. (1997), "Increasing Returns and the Genesis of American Resource Abundance." Industrial and Corporate Change 6, 203-245.

Deane, P. (1968), "New Estimates of Gross National Product for the United Kingdom 1830-1914." Review of Income and Wealth 14, 95-112.

Deane, P., and Cole, W. A. (1967), British Economic Growth 1688-1959. Trends and Structure. Cambridge, UK: Cambridge Univ. Press.

Denison, E. F. (1967), Why Growth Rates Differ. Postwar Experience in Nine Western Countries. Washington, DC: The Brookings Institution.

Dollar, D. (1992), "Outward-Oriented Developing Economies Really Do Grow More Rapidly: Evidence from 95 LDCs, 1976-1985." Economic Development and Cultural Change 40, 523-544.

Dormois, J. P., and Bardini, C. (1995), "La productivité du travail dans l'industrie de divers pays d'Europe avant 1914." Economies et Societes. Hietoire Quantitative de l'Economie Française. Serie A F 21 (12), 77-103.

Dowrick, S. (1998), "Quantifying Substitution Bias: True Comparisons of Prices and Quantities Across Countries." Presented at the PREM seminar Price and Purchasing Power Parities at the World Bank.

Dowrick, S., and Quiggin, J. (1997), “True Measures of GDP and Convergence.” American Economic Review 87, 41-64. 
Eckstein, A. (1955), “National Income and Capital Formation in Hungary, 1900-1950.” In S. Kuznets (Ed.), Income and Wealth, Series V. London: Bowes \& Bowes. Pp. 150-223.

Eddie, S. M. (1980), "Austria in the Dual Monarchy: Her Trade within and without the Customs Union." East Central Europe 7, 225-247.

Eichengreen, B. (1986), "What Have We Learned from Historical Comparisons of Income and Productivity?" In P. O'Brien (Ed.) International Productivity Comparisons and Problems of Measurement, 1750-1939. 9th International Economic History Congress, Session B6, Bern. Pp. $26-35$.

Ercolani, P. (1993), Il prodotto interno lordo dell'Italia nel lungo periodo Vecchie e nuove stime. Universitá di Ancona Studi sullo sviluppo, No. 1.

Estevadeordal, A. (1997), "Measuring Protection in the Early Twentieth Century." European Review of Economic History 1, 89-125.

Feder, G. (1983), "On Exports and Economic Growth." Journal of Development Economics 12, 59-73.

Feenstra, R. C. (1998), "Integration and Disintegration of Production in the Global Economy." Journal of Economic Perspectives 12, 31-50.

Feinstein, C. H. (1972), National Income, Expenditure and Output of the United Kingdom 1855-1965. Cambridge, UK: Cambridge Univ. Press.

Feinstein, C. H. (1998), “The United Kingdom in 1851. A Quantitative Picture of the Economy at Mid-Century." mimeo, University of Oxford.

Firestone, O. J. (1960), “Development of Canada's Economy, 1850-1900.” In W. N. Parker (Ed.), Trends in the American Economy in the Nineteenth Century. Studies in Income and Wealth, No. 24. Princeton, NJ: NBER Princeton University Press. Pp. 217-252.

Frankel, J. A., and Romer, D. (1999), "Does Trade Cause Growth?” American Economic Review 89, 379-399.

Fremdling, R. (1991), "Productivity Comparisons between Great Britain and Germany, 1855-1913." Scandinavian Economic History Review 29, 28-42.

Fremdling, R. (1995), “German National Accounts for the 19th and Early 20th Century." Scandinavian Economic History Review 43, 77-100.

Gilbert, M., and Kravis, I. B. (1954), An International Comparison of National Products and the Purchasing Power of Currencies. A Study of the United States, The United Kingdom, France, Germany and Italy. Paris: OEEC.

Gilbert, M., and associates (1958), Comparative National Products and Price Levels. A Study of Western Europe and the United States. Paris: OEEC.

Good, D. F. (1994), “The Economic Lag of Central and Eastern Europe: Income Estimates for the Habsburg Succesor States, 1870-1910." Journal of Economic History 54, 869-891.

Gregory, P. R. (1982), Russian National Income, 1885-1913. Cambridge, UK: Cambridge Univ. Press.

Hansen, S. A. (1974), Økonomisk væekst i Danmark. Copenhagen: Akademisk Forlag.

Hayami, Y., and Ruttan, V. W. (1985), Agricultural Development. An International Perspective. Baltimore: Johns Hopkins Univ. Press.

Heston, A., Nuxoll, D. A., and Summers, R. (1994), "The Differential Productivity Hypothesis and Purchasing Power Parities: Some New Evidence." Review of International Economics 2, 227-243.

Heston, A., and Summers, R. (1993), "What Can Be Learned from Successive ICP Benchmark Estimates." In A. Szirmai, B. van Ark and D. Pilat (Eds.), Explaining Economic Growth. Amsterdam: North-Holland. Pp. 353-373.

Heston, A., and Summers, R. (1996), "International Price and Quantity Comparisons: Potentials and Pitfalls." American Economic Review 86, 20-24.

Hjerppe, R. (1994), Finland's Historical National Accounts 1860-1994 Calculation Methods and Statistical Tables. Jyväskylä: J.Y.H.L.

Hodne, F., and Grytten, O. H. (1994), Gross Domestic Product of Norway 1835-1915. Occasional Papers in Economic History, Umeå University.

Hoffmann, W. G. (1965), Das Wachstum der Deutschen Wirtschaft seit der Mitte des 19. Jahrhunderts. Berlin: Springer-Verlag. 
Honohan, P. (1998), “Don’t Overdo PPP Adjustment of Real Output." Presented at the PREM seminar Price and Purchasing Power Parities at the World Bank.

Horlings, E. (1997), "The Contribution of the Service Sector to Gross Domestic Product in Belgium, 1835-1990." Mimeo, Universiteit Utrecht.

Hulsman-Vejsová, M. (1975), “Misleading Official Exchange-Rate Conversions.” Economic Journal 85, 140-147.

International Monetary Fund (various years), Balance of Payments Statistics. Washington.

International Labour Office (various years), Yearbook of Labour Statistics. Geneva.

Irwin, D. A. (1996), "The United States in a New Global Economy? A Century's Perspective." American Economic Review. Papers and Proceedings 86, 41-46.

Isenman, P. (1980), "Inter-Country Comparison of 'Real' (PPP) Incomes: Revised Estimates and Unresolved Questions." World Development 8, 61-72.

Jorgenson, D. (1993), "Comment on van Ark and Pilat." Brookings Papers on Economic Activity. Microeconomics 2, 49-56.

Justino, D. (1987), “Acerca da evoluçao do P.N.B. em Portugal (1850-1913).” Analise Social 97, $451-461$.

Justino, D. (1990), Preços e salarios em Portugal (1850-1912). História Económica 2. Lisbon: Banco de Portugal.

Kausel, A. (1979), “Österreichs Volkseinkommen 1830 bis 1913.” In Österreichisches Statistisches Zentralamt, Geschichte und Ergebnisse der zentralen amtlichen Statistik in Österreich 1829_ 1979, Beitraege zur öesterreichischen Statistik, Heft 550. Vienna.

Kennedy, K. A. (1971), Productivity and Industrial Growth. The Irish Experience. Oxford: Clarendon.

Kennedy, K. A. (1995), "The National Accounts for Ireland in the $19^{\text {th }}$ and $20^{\text {th }}$ Centuries," Scandinavian Economic History Review 43, 101-114.

Kostelenos, George (1995), Money and Output in Modern Greece, 1858-1938, Studies, Vol. 44. Athens: Centre of Planning and Economic Research (KEPE).

Kostis, C., and Petmezas, S. (1998), "Growth and Stagnation in the Greek Economy, 1830-1940." Mimeo.

Krantz, O. (1997), "Swedish Historical National Accounts 1800-1990. Aggregated Output Series." Umea University, mimeo.

Kravis, I. B. (1965), "Extrapolations of Real-Product and Purchasing-Power Comparisons." In J. Pincus (Ed.), Economic Aid and Cost Sharing. Baltimore: Johns Hopkins Univ. Press. Pp. 87-91.

Kravis, I. B. (1976), “A Survey of International Comparisons of Productivity.” Economic Journal 86, $1-44$.

Kravis, I. B. (1984), “Comparative Studies of National Incomes and Prices.” Journal of Economic Literature 22, 1-39.

Kravis, I. B., Heston, A , and Summers, R. (1978a), International Comparisons of Real Product and Purchasing Power. Baltimore: Johns Hopkins Univ. Press for the World Bank.

Kravis, I. B., Heston, A., and Summers, R. (1978b), "Real Per Capita Income for More than One Hundred Countries." Economic Journal 88, 215-242.

Kravis, I. B., Kenessey, Z., Heston, A., and Summers, R. (1975), A System of International Comparisons of Gross Product and Purchasing Power. Baltimore: Johns Hopkins Univ. Press for the World Bank.

Kravis, I. B., and Lipsey, R. E. (1983), Toward an Explanation of National Price Levels. Special Studies in International Finance, No. 52. Princeton, NJ: Princeton University Press.

Kravis, I. B., and Lipsey, R. E. (1987), “The Assessment of National Price Levels.” In S. W. Arndt and J. D. Richardson (Eds.), Real-Financial Linkages among Open Economies. Cambridge, MA: MIT Press. Pp. 97-134.

Kravis, I. B., and Lipsey, R. E. (1991), “The International Comparison Program: Current Status and Problems." In P. E. Hooper and J. D. Richardson (Eds.), International Economic Transactions Issues in Measurement and Empirical Research. Studies in Income and Wealth, Vol. 55. Chicago: NBER/Univ. of Chicago Press. Pp. 437-464.

Krejci, J. (1968), "Intertemporal Comparability of National Income in Czechoslovakia." Review of Income and Wealth 14, 247-266. 
Lains, P. (1995), A Economia portuguesa no seculo XIX. Crescimento economico e comercio esterno 1851-1913. Lisbon: Instituto de Ciências Sociais.

Lancieri, E. (1996), “The PPP Doctrine. LongTerm Exchange Rates and A New Method to Estimate Real Gross Domestic Products.” In D. S. Prasada Rao and J. Salazar-Carrillo (Eds.), International Comparisons of Prices, Output and Productivity. Amsterdam: North-Holland. Pp. 265-295.

Lazaretou, S. (1995), "Government Spending, Monetary Policies, and Exchange Rate Regime Switches: The Drachma in the Gold Standard Period." Explorations in Economic History 32, $28-50$.

League of Nations (various year), Statistical Yearbook. Geneva.

League of Nations (1943), Europe's Capital Movements, 1919-1932 A Statistical Note. Programme 15, G.P.V. 3 (statistics), mimeo.

Lethbridge, E. (1985), "National Income and Product.” In M. C. Kaser and E. A. Radice (eds.), The Economic History of Eastern Europe 1919-1975. I. Economic Structure and Performance between the Wars. Oxford: Oxford Univ. Press. Pp. 532-597.

Lévy-Leboyer, M., and Bourguignon, F. (1985), L'economie française au XIXe siecle. Paris: Economica.

Maddison, A. (1982), Phases of Capitalist Development. Oxford: Oxford Univ. Press.

Maddison, A. (1983), "A Comparison of Levels of GDP per Capita in Developed and Developing Countries, 1700-1980." Journal of Economic History 43, 27-41.

Maddison, A. (1989), The World Economy in the Twentieth Century. Paris: OECD Development Centre.

Maddison, A. (1991), Dynamic Forces in Capitalist Development. A Long-Run Comparative View. Oxford: Oxford Univ. Press.

Maddison, A. (1992), “A Revised Estimate of Italian Economic Growth, 1861-1989.” Banca Nazionale del Lavoro Quarterly Review 177, 225-241.

Maddison, A. (1995), Monitoring the World Economy 1820-1992. Paris: OECD.

Mata, M. E., and Valério, N. (1994), Historia Economica de Portugal. Uma perspectiva global. Lisbon: Presença.

Mitchell, B. R. (1988), Abstract of British Historical Statistics, Cambridge, UK: Cambridge Univ. Press.

Mitchell, B. R. (1992), International Historical Statistics. Europe 1750-1988. New York: Stockton Press.

Mitchell, B. R. (1993), International Historical Statistics. The Americas 1750-1988. New York: Stockton Press.

Mitchell, B. R. (1994), International Historical Statistics. Africa, Asia and Oceania 1750-1988. New York: Stockton Press.

Nelson, R., and Wright, G. (1992), "The Rise and Fall of American Technological Leadership: The Postwar Era in Historical Perspective." Journal of Economic Literature 30, 1931-1964.

Neves, J. C. das (1994), The Portuguese Economy. A Picture in Figures XIX and XX Centuries. Lisbon: Universidade Católica Editora.

North, D. C. (1960), “The United States Balance of Payments. 1790-1860.” In W. N. Parker (Ed.), Trends in the American Economy in the Nineteenth Century. Studies in Income and Wealth, Vol. 24. Princeton, NJ: Princeton Univ. Press. Pp. 573-627.

Nunes, A. B., Mata, M. E., and Valério, N. (1989), "Portuguese Economic Growth 1833-1985." Journal of European Economic History 18, 291-330.

Nuxoll, D. A. (1994), "Differences in Relative Prices and International Differences in Growth Rates." American Economic Review 84, 1423-1436.

O'Brien, P. K., and Keyder, C. (1978), Economic Growth in Britain and France 1780-1914. Two Paths to the Twentieth Century. London: Allen \& Unwin.

O'Brien, P. K., and Prados de la Escosura, L. (1992), "Agricultural Productivity and European Industrialization, 1890-1980.” Economic History Review 45, 514-536.

OECD (various year), National Accounts. Paris.

Officer, L. H. (1976), "The Purchasing-Power-Parity Theory of Exchange Rates: A Review Article." IMF Staff Papers 23, 1-60. 
Ó Gráda, C. (1994), Ireland. A New Economic History 1780-1939. Oxford: Clarendon.

Ohkawa, K., and Shinohara, M. (1979), Patterns of Japanese Economic Development. A Quantitative Appraisal. New Haven: Yale Univ. Press.

O'Rourke, K. H. (1995), “The Costs of International Economic Disintegration: Ireland in the 1930's." Research in Economic History 15, 215-259.

O’Rourke, K. H., Taylor, A. M., and Williamson, J. G. (1996), "Factor Price Convergence in the Late Nineteenth Century." International Economic Review 37, 499-530.

O’Rourke, K. H., and Williamson, J. G. (1994), "Late Nineteenth-Century Anglo-American Factor Price Convergence: Were Heckscher and Ohlin Right?" Journal of Economic History 54, 896-916.

O'Rourke, K. H., and Williamson, J. G. (1997), “Around the European Periphery 1870-1913: Globalization, Schooling and Growth." European Review of Economic History 1, 153-190.

Ozel, I. (1997), The Economy of Turkey in the Late Ottoman and Republican Periods A Quantitative Analysis. Unpublished M.A. Dissertation. Bogazisi University, Istanbul.

Pamuk, S. (1998), "Intervention in Response to the Great Depression: Another Look at the Turkish Case, 1929-1939," Presented at the Conference on Two Centuries of Economic Change in the Mediterranean Basin. Istanbul.

Perkins, D. H., and Syrquin, M. (1989), "Large Countries: The Influenc of Size.” In H. Chenery and T. N. Srinivasan (Eds.), Handbook of Development Economics. Amsterdam: North-Holland. Vol. II, pp. 1691-1753.

Pinheiro, M. (Ed.) (1997), Series longas para a economia portuguesa pos II Guerra Mundial. I. Series Estatisticas. Lisbon: Banco de Portugal.

Posthumus, N. W. (1946), Inquiry into the History of Prices in Holland. Amsterdam: Brill.

Prados de la Escosura, L. (2000a), "Globalization, Growth and Convergence since 1850: New Evidence for OECD Countries." Universidad Carlos III de Madrid, mimeo.

Prados de la Escosura, L. (2000b), "Output and Expenditure in Spain, 1850-1980." Madrid: Fundación Argentaria, mimeo.

Prasada Rao, D. S. (1993), Intercountry Comparisons of Agricultural Output and Productivity. Rome: FAO.

Pryor, F. L., Pryor, Z. P., Stadnik, M., and Staller, G. J. (1971), “Czechoslovak Aggregate Production in the Inter-war Period." Review of Income and Wealth 17, 35-59.

Rankin, K. (1992), “New Zealand's Gross National Product: 1859-1939." Review of Income and Wealth 38, 49-69.

Ritschl, A., and Spoerer, M. (1997), "Das Bruttosozialprodukt in Deutschland nach den amtlichen Volseinkommes- und Sozialproduktsstatistiken 1901-1995." Jahrbuch für Wirtschaftsgeschichte 2, 27-54.

Ritzmann-Blickenstorfer, H. (Ed.) (1996), Historische Statistik der Schweiz. Zürich: Chronos.

Ritzmann-Blickenstorfer, H. (1999), "Schätzung der gesamten Bruttowertschöpfung, 1891-1969." Mimeo,

Rogoff, K. (1996), “The Purchasing Power Parity Puzzle.” Journal of Economic Literature 34, $647-668$.

Rossi, N., Sorgato, A., and Toniolo, G. (1993), "I conti economici italiani: Una ricostruzione statistica." Rivista di Storia Economica 10, 1-47.

Samuelson, P. A. (1964), “Theoretical Notes on Trade Problems.” Review of Economics and Statistics 46, 145-154.

Samuelson, P. A. (1974), “Analytical Notes on International Real Income Measures.” Economic Journal 84, 595-608.

Samuelson, P. A. (1994), "Facets of Balassa-Samuelson: Thirty Years Later." Review of International Economics 2, 201-226.

Schneider, J., and Schwarzer, O. (1990), Statistik der Gold- und Wechselkurse in Deutschland (1815-1913). Berlin: Scripta Mercatorae Verlag.

Schneider, J., Schwarzer, O., and Schelzer, P. (1993), Statistik der Gold- und Wechselkurse in Deutschland und in Ostseeraum (18. Und 19. Jahrhunders). Berlin: Scripta Mercatorae Verlag. 
Schulze, M. S. (1997), "Re-Estimating Austrian National Income, 1870-1913: Methods and Sources." London School of Economics Working Papers in Economic History 36-97.

Simon, M. (1960), “The United States Balance of Payments, 1861-1900.” In W. N. Parker (Ed.), Trends in the American Economy in the Nineteenth Century. Studies in Income and Wealth, Vol. 24. Princeton, NJ: Princeton Univ. Press. Pp. 629-711.

Smits, J. P., Horlings, E., and van Zanden, J. L. (1999), “The Measurement of Gross National Product and its Components. The Netherlands, 1800-1913." N.W. Posthumus Instituut Research Memorandum.

Steckel, R. H., and Floud, R. (Eds.), Health and Welfare during Industrialization. NBER Project Report. Chicago: Univ. of Chicago Press.

Summers, R., and Heston, A. (1984), "Improved International Comparisons of Real Product and Its Composition: 1950-1980.” Review of Income and Wealth 30, 207-261.

Summers, R., and Heston, A. (1988), “A New Set of International Comparisons of Real Product and Price Levels Estimates for 130 Countries, 1950-1985." Review of Income and Wealth 34, 1-25.

Summers, R., and Heston, A. (1991), “The Penn World Table (Mark 5): An Expanded Set of International Comparisons, 1950-1988." Quarterly Journal of Economics 106, 327-368.

Summers, R., and Heston, A. (1993), “The Penn World Table (Mark 5.5)" (electronic version).

Summers, R., Kravis, I. B., and Heston, A. (1980), "International Comparisons of Real Product and Its Composition: 1950-77." Review of Income and Wealth 26, 19-66.

Svennilson, I. (1954), Growth and Stagnation in the European Economy. Geneva: UN Economic Commission for Europe.

Taylor, A. M. (1998), “Argentina and the World Capital Market: Saving, Investment, and International Capital Mobility in the Twentieth Century." Journal of Development Economics 57, 147-184.

Toutain, J. C. (1997), "Le produit intérieur brut de la France, 1789-1990." Economies et Societes, Histoire Economique Quantitative, Serie HEQ 1(11), 5-136.

United Nations (1949), International Capital Movements during the Inter-war Period. Department of Economic Affairs. Lake Success, N.Y.

UNESCO (1963, 1974), Statistical Yearbook. New York.

United Nations (various years), Statistical Yearbook. New York.

United Nations (various years), Demographic Yearbook. New York.

Urquhart, M. C. (1986), "New Estimates of Gross National Product, Canada, 1870-1926: Some Implications for Canadian Development." In S. L. Engerman and R. E. Gallman (Eds.), Long-Term Factors in American Economic Growth. Studies in Income and Wealth, vol. 51. Chicago: NBER/University of Chicago Press. Pp. 9-94.

Valério, N. (1998), "Recent Developments on Portuguese Retrospective National Accounts." GHES Working Papers, No. 12.

van Ark, B. (1993), “The ICOP Approach. Its Implications and Applicability.” In A. Szirmai, B. van Ark, and D. Pilat (Eds.), Explaining Economic Growth. Amsterdam: North-Holland. Pp. 375-398.

van Zanden, J. L. (1991), “The First Green Revolution: The Growth of Production and Productivity in European Agriculture, 1870-1914.” Economic History Review 44, 215-239.

Weiss, T. (1994), “Economic Growth before 1860: Revised Conjectures.” In T. Weiss and D. Schaefer (Eds.), American Economic Development in Historical Perspective. Stanford: Stanford University Press. Pp. 11-27.

West, E. C. (1967), "Real Income Comparison Canada-United States 1965 and Selected Years Back to 1950." Technical Appendix to D. J. Daly and D. Walters, "Factors in Canada-United States Real Income Differences." Review of Income and Wealth 13, 285-309.

Williamson, J. G. (1995), “The Evolution of Global Labour Markets since 1830: Background Evidence and Hypotheses." Explorations in Economic History 32, 141-196.

Williamson, J. G. (1996), “Globalization, Convergence, and History.” Journal of Economic History 56, 277-306.

Wright, G. (1990), “The Origins of American Industrial Success, 1879-1940.” American Economic Review 80, 651-668. 